\title{
Childhood adversity, educational trajectories, and self-reported health in later life among U.S. women and men at the turn of the century
}

\author{
Angela M. O’Rand · Jenifer Hamil-Luker · Cheryl Elman
}

\begin{abstract}
A major objective of current life course research is to specify the processes linking early childhood conditions to subsequent life course statuses that span educational, occupational, familial, and health domains across the life span. This study confronts at least two persistent challenges to the rigorous specification of the relationships among these variables. The first is that the point-in-time measurement of education as "years of schooling" masks considerable heterogeneity in the timing and curricular tracks of schooling and obscures our understanding of how and when education matters for life-course inequality. The second challenge involves interdependencies between aspects of life-course inequality, including educational achievement and health. The intertwining of these variables across the life course, and their usual conceptualization and measurement, limit the interpretation of their relationship and its generalizability across studies. We use data from three waves of the National Survey of Families and Households between 1987-1988 and 2001-2002 to explore trajectories of self-reported health, applying latent class cluster analysis (finite mixture models) to deal directly with these measurement and specification issues. Generally, we find mediating effects of education in mid- to late-life health demonstrating the pivotal role of education in life course processes. Women's childhood backgrounds are more heterogeneous and temporally complex educational careers affect their self-assessed health more than men's. Late degrees are linked to poor health trajectories among women, but not men. Also, marital history, number of births and health behaviors are associated in expected ways with women's and men's health trajectories at midlife.
\end{abstract}

Keywords: Childhood adversity $\cdot$ Educational attainment $\cdot$ Gender $\cdot$ Midlife health

Online publiziert: 06.10 .2009

(C) VS-Verlag 2009

Prof. A. M. O'Rand, Ph.D. ( $\varangle)$

Department of Sociology, Duke University, 27708 Durham, USA

e-mail: aorand@soc.duke.edu

Prof. J. Hamil-Luker, Ph.D.

Department of Sociology, University of North Carolina, Greensboro, USA

e-mail: JLHAMILL@uncg.edu

Prof. C. Elman, Ph.D.

Department of Sociology, University of Akron, Akron, USA

e-mail: cheryl2@uakron.edu 


\section{Kindheitsprobleme, Bildungslaufbahn und selbstberichteter Gesundheitszustand im späteren Leben von U.S.-amerikanischen Frauen und Männern um die Jahrhundertwende}

Zusammenfassung: Ein Hauptaugenmerk der gegenwärtigen Lebenslaufforschung gilt der Spezifizierung der Prozesse, die die Lebensbedingungen in der frühen Kindheit mit den späteren Lebensphasen in Bezug auf (Schul-)Bildung, Berufsbildung, Familie und Gesundheit in Beziehung setzen. Diese Studie stellt in mindestens zwei Problemfeldern eine Herausforderung zu der vorherrschenden Spezifizierung der Zusammenhänge zwischen diesen Variablen heraus: Die derzeit übliche Messung von Bildung in „Jahren der Beschulung“ verschleiert erstens die beträchtliche Heterogenität in der Terminierung und in den unterschiedlichen Bildungsgängen der Beschulung und vernebelt unser Verständnis, „wie?“ und „warum?“ Bildung eine so große Wirkung auf die Ungleichheit im Leben hat. Die zweite Herausforderung geht einher mit den Wechselwirkungen zwischen Lebenslaufungleichheiten wie Bildungsniveau und Gesundheit. Das Ineinandergreifen dieser Variablen im Verlauf des Lebens sowie ihre übliche Konzeptualisierung und Messung begrenzt die Interpretation der Zusammenhänge und die Generalisierbarkeit von solchen Studien. In diesem Beitrag werden drei Wellen der „National Survey of Families and Households“ zwischen 1987/88 und 2001/02 genutzt, um die Zustandskurve der selbstberichteten Gesundheit zu erforschen, wobei latente Klassen-Clusteranalysen (finite Mischungsmodelle) verwendet wurden, um diese Messungen und Spezifizierungen zu verarbeiten. Generell fanden wir vermittelnde Effekte der Bildung auf den Gesundheitszustand im mittleren und späteren Leben, was die besondere Rolle der Bildung für den späteren Lebensverlauf herausstellt. Die Kindheiten von Frauen in den U.S.A. verliefen heterogener und die zeitlich komplexen Bildungsverläufe bei Frauen hatten größere Auswirkungen auf den selbsteingeschätzten Gesundheitszustand als bei den Männern. Späte Abschlüsse sind bei Frauen mit schlechtem Gesundheitszustand verbunden, nicht aber bei Männern. Der Eheverlauf, die Zahl der Geburten und das Gesundheitsverhalten sind in der erwarteten Weise mit dem Gesundheitszustand von Frauen und Männern im mittleren Lebensalter verknüpft.

Schlüsselwörter: Kindheitsprobleme $\cdot$ Bildungslaufbahn $\cdot$ Gender $\cdot$ Gesundheit im mittleren Lebensalter

A goal of life course research is to specify the processes that link early childhood conditions to subsequent life course trajectories that range across educational, occupational, familial, and health domains over the life span. One focus of this research is on the mediating effects of education, usually measured as years of schooling, on mid- and late-life outcomes such as earnings and health. Applying a cumulative disadvantage framework, this study adds to this tradition by using longitudinal data to examine relationships among childhood adversity, educational trajectories, and adult health trajectories in a manner sensitive to gender-specific life course linkages between education and adult health. Patterns of educational attainment among women and men have not been equivalent nor remained constant over the last 40 years, leaving unanswered questions about genderspecific trajectories of educational attainment and midlife outcomes such as health.

This study confronts two persistent challenges to the rigorous specification of the relationships among these variables. The first is that the point-in-time measurement of education as "years of schooling" masks considerable heterogeneity in the timing and curricular tracks of schooling that may provide an improved substantive understanding of how and when education matters for life-course inequality. Some efforts have been made in this direction (see Ross and Mirowsky 1999; Elman and O'Rand 2004; House et al. 
2005), but more is yet to be done. The second challenge is the issue of the interdependence between aspects of life course inequality, including educational achievement and health. The intertwining of these variables across the life course limits the interpretation of their relationship and its generalizability across studies.

We apply latent class cluster analysis to deal directly with these measurement and specification issues. This approach directly identifies multiple trajectories of schooling and health and models their interdependence. By doing so, the analysis helps to "unpack" the association between diverse and unequal educational pathways and trajectories of health in later life and to reveal the gender-specific effects of early childhood adversity on health trajectories controlling for important co-occurring and intervening life course transitions, health behaviors, and personal attitudes.

\section{Childhood adversity, educational trajectories and adult health}

Stratification over the life course is driven by patterns of cumulative advantage and disadvantage that begin in childhood. Childhood exposures to poor health, economic deprivation and family instability create conditions that have long term effects on individual development (McLeod and Almazan 2003), socioeconomic attainments (Elman and O'Rand 2004), health maintenance (O'Rand and Hamil-Luker 2005), and mortality (Hayward and Gorman 2004).

Initial inequalities are fundamental conditions that constrain the acquisition and maintenance of what has been referred to as "life course capital" - or the cumulative stock of interdependent economic, social, personal, and physical resources to manage expected and unexpected life transitions and events (O'Rand 2001). Earlier disadvantages exert a social gravity on later resource acquisitions, beginning with lower levels of educational attainment and extending to less advantaged work and family careers and higher risks for illness and mortality over time. Earlier advantages become resources that generate further relative gains and buffer the impact of later shocks or losses. Accordingly, the sequential contingency of life statuses is the probabilistic process of stratification from birth to death.

The persistent association of childhood conditions with adult illness/health is not a matter of major dispute. A growing literature reports this association across many datasets. Poor child health predicts poor self-assessed health in adulthood (Elo 1998) and raises the risks of chronic diseases such as cancer, lung disease, cardiovascular conditions and arthritis and rheumatism in late middle-age (Blackwell, Hayward, and Crimmins 2001). Childhood chronic illness and low socioeconomic status lead to worsening health conditions in childhood (Case, Lubotsky, and Paxson 2002). Economic hardship in childhood, especially sustained hardship, is associated with lower adult SES, poorer physical and mental health in adulthood, and higher death rates across western countries (e.g. Kuh and Davey Smith 1997; Harper et al. 2002).

Childhood family instability and distress are also implicated in later adult health. Parental divorce and marital distress create unstable environments of mistrust, distraction, and parental inattention. Resources for the support and nurturance of healthy and unhealthy children are strained and stretched thin as a result of family distress, even in 
intact households (Wickrama, Lorenz, and Conger 1997). Health-related behaviors such as regular bedtimes and home-prepared meals, etc., are often sacrificed in these environments (Case, Lubotsky, and Paxson 2002).

What remains problematic is the theoretically-consistent and empirically-grounded identification of the social and individual mechanisms that link specific childhood conditions to specific adult outcomes. Because current research consists of widely varying mixes of aggregate-level, individual-level, cross-sectional and longitudinal studies of varying representativeness and of diverse covariates and adult outcomes, theoretical coherence has been difficult to achieve. The most promising approaches for uncovering these mechanisms reside in longitudinal analyses with detailed prospective and/or retrospective information on life course transitions from childhood to midlife.

\section{Educational attainment and health}

The correlation between educational attainment and health in adulthood is as widely reported as that between childhood conditions and adult health in the U.S. (Mirowsky and Ross 2003). The most frequent argument is that human capital accumulation mediates the effects of social origins. Reynolds and Ross (1998), for example, argue that level of education is an achieved status that serves as a proxy for unmeasured factors such as substantive learning, socialization, positive personal outlooks, and health attitudes. This tradition also argues that marginal returns from each additional year of schooling are higher among the most disadvantaged populations (Mirowsky and Ross 2003) and over time reduce the disparities in economic, social and personal resources observed in early life.

Following this pattern, education is associated with better health and longevity, though House and his colleagues (2005) argue that education's effects are strongest in predicting the onset of disease while other SES factors such as income or health insurance influence the course of disease. However, mixed findings across studies suggest that educational attainment appears both to reproduce (and sometimes amplify) the effects of childhood inequalities or under some conditions (or for some status groups, such as gender) to mediate their effects. For example, recent studies of the impact of childhood adversity on risk for heart attack finds that childhood adversity has persistent effects on heart attack risk after controlling for intervening life transitions and that education amplifies these effects (O'Rand and Hamil-Luker 2005), but that women are more vulnerable to these persistent effects than men whose encounters with intervening resources can diminish the impact of adverse childhoods (Hamil-Luker and O'Rand 2007).

Studying educational careers in the American system. This analysis does not seek to adjudicate among or account in detail for all these patterned variations but argues that educational attainment within U.S. cohorts is a complex and protracted process with individual and structural components that have been under-appreciated. Because the educational career itself is typically not observed directly as a process, the education-health correlation becomes masked by summary measures, such as "years of schooling". Data limitations, in part, account for this; detailed educational histories are available in only a few databases and are often not accompanied by comparable health information. 
However, research conventions also adhere to assumptions about educational trajectories that mask heterogeneities across individuals. Two of these assumptions are that (1) education is completed by early adulthood and (2) "years of schooling" sufficiently captures a universally experienced substantive process of human capital accumulation. The former assumption goes unquestioned throughout most of the research literature. The latter has been directly entertained as "years of school" but ignores unobserved heterogeneity within educational careers-in timing of enrollment or completion, durations over the life course, and institutional tracks.

Yet educational careers have become more temporally heterogeneous and school attainment trajectories have become more stratified in the U.S. (Bernhardt et al. 2001; Elman and O'Rand 2007), especially disadvantaging women and ethnic minorities. Succeeding cohorts of Americans born after the Second World War have attended diverse secondary and post-secondary educational institutions at higher rates and over longer periods of their lives (Jacobs and Stoner-Eby 1998). Many adults interrupt educational careers to fulfill other roles or renew educational careers in response to work-related demands or fears of job loss (Elman and O'Rand 2002). For example, in the 1999-2000 academic year, over 40 percent of college students were older than age 24, a figure nearly double the rate twenty years earlier. Diversity in the timing of education is accompanied by differentiated experiences across non-academic vocational technical tracks in business, nursing and similar institutions, raising questions regarding the attribution of universal benefits to a simple summary of years of schooling.

Timing of educational completion has also been implicated in later attainment outcomes, especially in wage attainment. The completion of baccalaureate degrees by normative ages (22-24) has been associated with wage advantages over the life course when compared to the later attainment of these credentials (Elman and O'Rand 2004; Taniguchi 2005; Monks 1997). Early baccalaureate completion moves individuals to the labor market earlier to initiate work and earnings trajectories with cumulative (compounding) advantages in wage growth, positional mobility, and employee benefit wealth. Thus, years of schooling matters, but without a temporal accounting of the timing of degree completion, the manner in which schooling affects health is not well specified.

The increased heterogeneity and timing of these educational careers across adulthood has potentially important implications for analyzing health outcomes. Health careers develop at the same time as educational careers in this context. Chronic health conditions whose symptoms often begin to appear in midlife are anchored in earlier life experiences and cumulative trajectories and they, in turn, condition the course of educational, work and family careers. While it has been argued that the path from education to health is stronger than the reverse path (House et al. 2005), the measurement of education in this research remains a point-in-time indicator based on the assumptions discussed earlier.

\section{Gender, life course and health}

Women's health over the life course appears to be worse than men's, although men have higher mortality. This is often referred to as the health-survival (or morbidity-mortality) paradox (Rieker and Bird 2000). We understand very little about this paradox, though we 
now have the opportunity, by using long-term longitudinal databases, to uncover some of the gender-specific mechanisms that are influential in producing it and the conditions under which it occurs. Women's poorer health is generally attributed to gender inequality over the life course. Women have more difficulties overcoming early childhood adversity because of their lower occupational opportunities and greater responsibilities for childbearing, childrearing, and general kin keeping responsibilities (Gornick and Meyers 2003; Epstein and Kalleberg 2004; Schnittker 2007). They experience higher levels of role conflict and stress related to multiple role incumbency that results in higher levels of physical and mental illness (Rieker and Bird 2000). Consequently, their patterns of educational attainment have been lower or delayed due to life course interruptions (Taniguchi and Kaufman 2005) with negative consequences for well-being across economic and health domains.

Recent college cohorts contradict this pattern with baccalaureate achievement patterns that favor women (Goldin et al. 2006; DiPrete and Buchmann 2006). Women are graduating from college at higher rates than men and are benefiting from college graduation in terms of their marriageability, improved standard of living measured as household income, and insurance against poverty. This trend is apparent across western industrialized societies (Goldin et al. 2006). Women may also be improving in their health relative to men. Recent aggregate studies suggest that women's self-reported health has improved over the past decade (Schnittker 2007), despite persistent evidence of health declines associated with childcare demands combined with workplace obligations (Epstein and Kalleberg 2004). Men's self-reported health has historically exceeded women's across ages, but recent trends suggest a gender cross-over in self-reported health that favors women (Schnittker 2007).

These apparently contradictory patterns of gender health disparities but improved health equality still mask the underlying inequalities in overall patterns of educational careers. Gender gaps in educational careers and in health outcome persist. And, women are becoming more unequal among themselves in well-being (Blau 1998). Even if their average patterns of wellbeing appear to be improving, women's relative well-being based on life course factors is producing disparities and increased inequalities among them and between them and men.

\section{Anchoring effects of childhood, pivotal effects of education and persistent effects of gender}

Cumulative dis/advantage theory is best suited for this task (Dannefer 2003; DiPrete and Eirich 2006). But it places strong conceptual and analytical demands on measurement and modeling that are not always met. It proposes a general mechanism for inequality across time (or with age) whereby outcomes are biased in the direction of initial inequalities. In the strictest adherence to the theory, the outcomes are probably best conceptualized themselves as trajectories over time rather than as point-in-time levels of resources or status. DiPrete and Eirich (2006) point to the distinction between measuring outcomes as levels of resources or statuses or as growth rates (or trajectories) of resources or statuses over time. Both approaches are taken in the wide-ranging literature on cumulative processes, 
but the latter is more tightly connected to the theory. Hence, the temporal requirements of the theory include careful measurement of initial inequalities (resource levels) and trajectories of accumulation (or decline) that follow over the life course. This stricter application of the theory favors micro-level longitudinal data with repeated measurements and the consistent parameterization of covariates to capture cumulative processes of advantage or disadvantage including the influence of both normative, contingent and random events and transitions.

Cumulative dis/advantage theory also has a strong sociological basis. The cumulative process does not only refer to the individual biography of resource or status accumulation. The theory provides a social allocation logic that explicitly proposes that structural processes of social attribution and stratification work to favor or reward early levels of advantage or higher perceived achievement in the life course and, by default or design, to penalize early levels of disadvantage or lower perceived achievement. Terms such as "first mover advantage," "path dependent increasing returns," "halo effect," "virtuous cycle," "vicious cycle," "signaling," "assortative mating," etc. pervade the labor market, stratification, family and organizational literatures and refer directly and indirectly to social attribution processes that differentially value kinds of educational achievement and the timing of that achievement (see DiPrete and Eirich 2006 for references to these literatures). Hence, the structural allocation of individual attributes deserves explicit treatment. Gender, race, class of origin and educational attainment are among those socially recognized attributes that contribute to persistent and growing inequalities over the life course.

Hypotheses. Cumulative advantage theory predicts that life course stratification is a complex process of self-reinforcing trajectories of interdependent resources. Cumulative disadvantage theory also argues that educational trajectories are probably stratified by unequal advancement potentials across vocational or nonacademic vs. baccalaureategranting tracks (Elman and O'Rand 2007), which are themselves contingent on childhood origins to the extent that baccalaureate tracks are positively associated with advantaged social origins. Hence, childhood conditions have anchoring effects on later attainments or wellbeing. In addition, cumulative advantage theory would argue that earlier - as opposed to later - completion of academic degrees compounds gains over the life course as individuals are rewarded in labor and marriage markets earlier in life. Thereby, the early timing of rewards can accumulate multiple resources to delay midlife health declines. In addition, to the extent that individuals overcome earlier disadvantages by attaining higher educational credentials by adulthood, educational careers can have pivotal effects on later attainments or wellbeing.

Finally, gendered patterns of inequality over the life course are probably initiated in childhood and accumulate over time in a process that places women in sequentially disadvantaged positions that are obstacles to overcoming childhood disadvantages; this generates and sustains persistent gender disparities in health. These hypotheses do not intend to displace any arguments that forms and levels of education provide human capital that can be converted to earnings, marriageability, healthy life styles, and good health. But a more direct accounting of the diverse gender trajectories of education and health in adulthood moves us in the direction of a better structural accounting of this relationship. 


\section{Data and measures}

The data used for this analysis come from the National Survey of Families and Households, a nationally-representative, longitudinal study. The first wave, conducted in 1987-1988, includes double samples of African Americans, Hispanic Americans, single parents and families with stepchildren, as well as cohabiting and recently married couples $(n=13,008)$. It provides life history information on childhood living conditions, adult health and a detailed education history as well as general information about demographic, social, and economic aspects of American family life (Sweet, Bumpass and Call 1988). Main respondents were re-interviewed in 1992-1994 $(n=10,008)$ and in a third wave, conducted in 2001-2003, of respondents aged 45 or older or with a focal child in a prior wave $(n=4600)$. Content in Waves 2 and 3 update health, education, employment, and family histories since the first interview. Because we are interested in the linkages between health and education trajectories as individuals move from early adulthood into old age across all three waves, we limit our sample to the 3798 respondents who were aged 30 and older at Wave 1 and who provided information on selected measures.

Dependent variable and demographics. The outcome measure of interest is self-reported poor health. For each of the three waves, we create a dummy variable coded 1 for those who describe their health as fair, poor or very poor and coded 0 for those who report their health as excellent or good in comparison to others their age. Table 1 reports descriptive statistics for included measures and shows how the likelihood of self-reported poor health increased over time. Demographic measures include age, sex, and racelethnicity (Black and Hispanic compared to all others).

Childhood background. To assess how processes of cumulative disadvantage rooted in early living conditions shape health trajectories, we use a series of retrospective measures of respondents' social origins collected during Wave 1. NSFH respondents reported whether or not their families received public assistance when growing up. Family structure measures include number of siblings in the household while respondents were growing up and whether or not respondents lived in a single parent household, operationalized as not living with both biological parents at age 16. To measure parental education, we include two dichotomous indicators of whether or not mothers and fathers completed less than 12 years of schooling. We compare respondents who reported their father was unemployed or disabled when they were 16 to those with employed fathers. Finally, respondents reported the type of work their father did when they were 16. Occupation information was used to calculate father's occupational socioeconomic index score, as recoded by Stevens and Cho (1985).

Educational trajectories. To assess which components of education are most strongly related to health trajectories, we measure several temporal aspects of education, including educational attainment (number of years of completed schooling at each wave), pathways to attainment (age of enrollment in various types of schools), and education credentialing (degree completion and age of degree completion). Educational attainment, which ranges from 0 to 20 , is measured as the highest elementary or secondary grade 
Table 1: Descriptive Statistics from NSFH Respondents in Waves 1, 2, and 3; N=3798

\begin{tabular}{|c|c|c|c|}
\hline & Mean & Std. Dev. & Range \\
\hline \multicolumn{4}{|l|}{ Self-reported Health } \\
\hline Poor/fair health W1 & 0.16 & 0.37 & $0-1$ \\
\hline Poor/fair health W2 & 0.21 & 0.41 & $0-1$ \\
\hline Poor/fair health W3 & 0.27 & 0.44 & $0-1$ \\
\hline \multicolumn{4}{|l|}{ Demographics and Family Background } \\
\hline Age in Wave 3 & 60 & 11.45 & $43-100$ \\
\hline Black & 0.13 & 0.34 & $0-1$ \\
\hline Hispanic & 0.03 & 0.18 & $0-1$ \\
\hline Male & 0.37 & 0.48 & $0-1$ \\
\hline Early public assistance & 0.08 & 0.27 & $0-1$ \\
\hline Single-parent household & 0.23 & 0.42 & $0-1$ \\
\hline Number of siblings in hh & 3.60 & 2.67 & $0-20$ \\
\hline Mom no high school degree & 0.37 & 0.48 & $0-1$ \\
\hline Dad no high school degree & 0.38 & 0.49 & $0-1$ \\
\hline Dad's occupational SEI & 0.30 & 0.19 & $0-0.90$ \\
\hline Dad unemployed/disabled & 0.13 & 0.29 & $0-1$ \\
\hline \multicolumn{4}{|l|}{ Alternative Measures of Education } \\
\hline Years of completed schooling & 13.44 & 2.86 & $0-20$ \\
\hline Age enrolled in business/nursing school & 22.96 & 11.02 & $15-73$ \\
\hline Age enrolled in vocational/technical school & 24.08 & 10.63 & $15-76$ \\
\hline Age enrolled in junior/community college & 23.69 & 10.89 & $16-75$ \\
\hline Age enrolled in four-year university & 21.42 & 9.64 & $17-73$ \\
\hline Age enrolled in grad/professional school & 27.90 & 9.22 & $18-64$ \\
\hline High school degree by Wave 3 & 0.85 & 0.44 & $0-1$ \\
\hline Associate's degree by Wave 3 & 0.10 & 0.21 & $0-1$ \\
\hline Bachelor's degree by Wave 3 & 0.25 & 0.39 & $0-1$ \\
\hline Graduate degree by Wave 3 & 0.13 & 0.25 & $0-1$ \\
\hline Age completed high school degree or GED & 18.90 & 4.24 & $15-65$ \\
\hline Age completed Associate's degree & 29.23 & 10.76 & $16-66$ \\
\hline Age completed Bachelor's degree & 25.15 & 6.97 & $17-68$ \\
\hline Age completed graduate degree & 32.21 & 8.53 & $21-63$ \\
\hline \multicolumn{4}{|l|}{ Employment and Economic Resources W3 } \\
\hline Employed & 0.57 & 0.50 & $0-1$ \\
\hline Manager/professional & 0.27 & 0.44 & $0-1$ \\
\hline Household income (logged) & 5.53 & 2.87 & $0-13.83$ \\
\hline Worry about income & 0.24 & 0.43 & $0-1$ \\
\hline Has health insurance & 0.84 & 0.36 & $0-1$ \\
\hline \multicolumn{4}{|l|}{ Social Ties } \\
\hline Ever divorced & 0.42 & 0.49 & $0-1$ \\
\hline Difficult relationships & 0.17 & 0.37 & $0-1$ \\
\hline No socializing $\mathrm{w} /$ friends & 0.30 & 0.46 & $0-1$ \\
\hline
\end{tabular}


Table 1: (continued)

\begin{tabular}{lccc}
\hline & Mean & Std. Dev. & Range \\
\hline Health Behaviors & & & \\
Non-drinker & 0.53 & 0.50 & $0-1$ \\
Heavy drinker & 0.01 & 0.27 & $0-1$ \\
Current smoker & 0.16 & 0.36 & $0-1$ \\
Ever smoked & 0.36 & 0.48 & $0-1$ \\
Obese & 0.25 & 0.43 & $0-1$ \\
Competency scale & 11.78 & 1.83 & $4-15$ \\
Personal control scale & 14.49 & 2.69 & $4-20$ \\
\hline
\end{tabular}

level completed or the highest postsecondary degree level obtained from a college, university, or professional school. Because we are interested in possible health effects of the timing of school enrollment, we use the detailed education histories collected over three waves to depict pathways to attainment. Excluding correspondence courses and schools at which they took two or fewer courses or attended less than six weeks, respondents provided information on the dates at which they enrolled in five types of postsecondary schools: vocational, technical, or trade school; two-year junior or community college; business college, secretarial, or nursing school; four-year college or university; and professional or graduate school requiring prior college work for entrance. Using three waves of data, we create dummy variables measuring whether or not respondents enrolled in each of the school types during a series of age groupings $(<=19,20-24,25-29,30-34$, $35-39,40-49,50-59,60-69,70+$ ). Latent class cluster analysis, as described below, used these 45 dummy variables to identify groups of respondents who followed similar school enrollment trajectories as they aged.

We assess the credentialing effect of education by creating a series of dummy variables measuring whether or not respondents completed a high school diploma, Associate's degree, Bachelor's degree, Master's degree, or Doctoral degree by Wave 3. Using reported age of degree completion, we create a series of dummy variables comparing those who completed the degree "on-time" (by age 19 for high school, 24 for Associate's and Bachelor's, and 30 for graduate degree) to those who completed the degree "late" (after the above age cut-offs). Selection of these normative ages was based upon examination of national averages (U.S. Department of Education 2006, 2001, 2000) and the mean and median response for NSFH respondents.

Table 1 reports descriptive statistics for these alternative measures of education. On average, NSFH respondents are high school graduates who are likely to enroll in various types of schools as they age, but not necessarily complete degrees. For example, while $90 \%$ of respondents took classes in a four-year university at some point in their education careers, only $25 \%$ completed a Bachelor's degree. Further analyses will test whether this school enrollment, despite non-degree completion, is associated with the risk of poor health trajectories. Table 1 also highlights the heterogeneity in age of degree completion. Although typical measures of education assume that education levels are set by young adulthood, 20\% of NSFH respondents who complete an Associate's or graduate degree do so in their 40s, 50s, and 60s. Six percent of Bachelor's degrees are obtained after an NSFH respondent's 40 th birthday. 


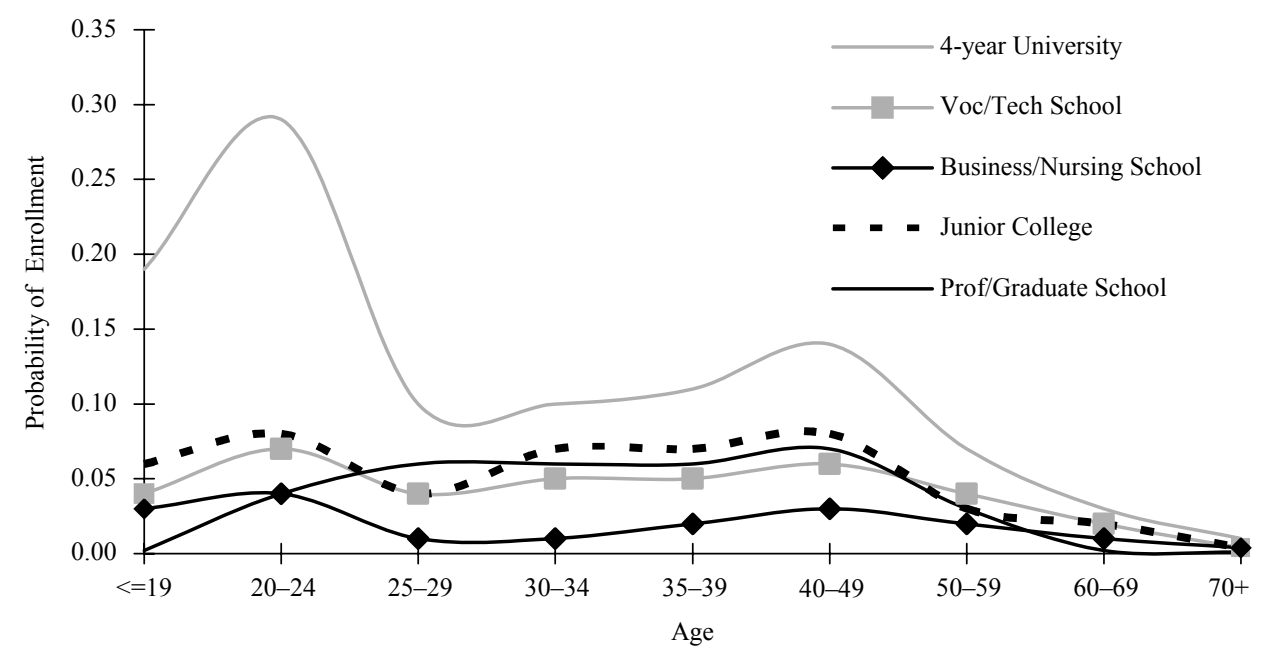

Fig. 1: Average Probability of School Enrollment by Age and Type of School for NSFH Respondents Followed in Waves 1, 2, and 3; $\mathrm{N}=3798$

Figure 1 reveals a complex, protracted pattern of educational engagement by summarizing the average probability of school enrollment by age and type of school for respondents followed between 1987 and 2002. Figure 1 highlights the nontrivial likelihood of school enrollment into middle age.

Employment and economic resources. To test the hypotheses that accumulated economic, social, and psychological resources shape education and health trajectories and mediate the relationship between childhood living conditions and risk of poor health in adulthood, our models add blocks of covariates moving from more structural to more individuallevel resources. Employment measures collected during Wave 3 include employment status and occupation. We compare managers and professionals to all other occupations. Economic resources assessed at Wave 3 include household income (logged and adjusted for family size), access to health insurance, and whether or not respondents worry that their income cannot meet family expenses often or all of the time.

Social ties. Measures of social ties include number of children born or whether or not respondents were ever divorced by Wave 3. Wave 3 respondents also reported how often they got together to socialize with friends. Answers range from $0=$ never to $4=\mathrm{sev}-$ eral times a week. We compare those who reported they got together less than once a year with friends to those who answered once a month, once a week, or several times a week. Respondents who agreed or strongly agreed that maintaining close relationships is difficult and frustrating are compared to those who reported no difficulty maintaining relationships.

Health behaviors. Next, we use health behavior data collected during Wave 3 . We compare those who reported they did not drink alcohol in the past month (non-drinkers) and 
those who reported having more than 5 drinks on one occasion in the past month (heavy drinkers) to those who drank alcohol but not 5 or more drinks on one occasion (moderate drinkers). We compare current smokers and those who smoked in the past (ever smoked) to those who never smoked. Finally, we include a measure of obesity, defined as having a body mass index of 30 or greater calculated from self-reported height and weight.

Personal competence and control. Through the development of various skills and abilities, formal education teaches people how to solve problems and be active agents in shaping their own lives (Ross and Mirowsky 1989). In their theory of learned effectiveness, Mirowsky and Ross (2003) postulate that much of education's positive effect on health comes from instilling the belief that individuals can affect their own futures and thus adopt health-promoting lifestyles. In short, more highly educated individuals have a sense of competency and personal control that are conducive to better health. Competency may be defined as the belief that one is capable of enacting certain behaviors successfully. People with a high sense of personal control believe they can master their own environments while those with a low sense of personal control believe that one's actions do not affect outcomes (Mirowsky and Ross 2003).

To test whether competence and sense of personal control help explain the link between education and health, we created 2 scales measuring these psychological resources at Wave 3 . On a scale ranging from 1 to 5 where (after reverse-coding) $1=$ strongly disagree and $5=$ strongly agree, respondents reported the extent to which they agreed with the following statements: a) I can do just about anything I really set my mind to do, (b) I am able to do things as well as other people, and (c) I am quite good at managing the many responsibilities of my daily life. The competency scale summed responses on these three items and had an alpha of 0.64 . The personal control scale (alpha $=0.62$ ) consists of summed responses to the following items: (a) Sometimes I feel that I'm being pushed around in life, (b) There is really no way I can solve some of the problems I have, (c) I have little control over the things that happen to me, and (d) In general, I feel I am in charge of the situation in which I live. The original coding scheme $(1=$ strongly agree to $5=$ strongly disagree) was reversed for item $d$ so that higher responses indicate higher levels of perceived personal control.

\section{Methods}

We use latent class (LC) cluster analysis, also known as group-based trajectory modeling (Nagin 2005), to identify groups of respondents who follow similar educational and health trajectories, respectively, over time. These models also allow for the inclusion of covariates to predict membership in the identified health and education trajectories. LC cluster models assume that measured indicators are associated because the overall study population is comprised of a mixture of $J$ subpopulations or classes (Bandeen-Roche et al. 1997). The analyses are based on an assumption that a small number of distinct patterns of responses fit the set of observable indicators (e.g., self-reported health during Waves 1, 2 and 3) and reflect substantively meaningful yet latent individual characteristics (Yamaguchi 2000). This specialized application of finite mixture modeling identifies 
(rather than assumes the existence of) groups of distinctive developmental trajectories and captures the connectedness of behavior over time.

Schooling trajectories. First, we use LC cluster analysis to identify groups of respondents who share similar patterns of school enrollment as they age. Using maximum likelihood estimation and Latent Gold software, LC cluster analysis allows us to identify patterns of enrollment by age and type of school that would be impossible to distinguish using sample averages. As described above, we have 45 measures of whether or not respondents enrolled in voc/tech schools, junior colleges, business/nursing schools, four-year universities, and professional/graduate schools during subsequent age categories. In the LC cluster model, the probability of obtaining a specific response pattern $y, P(Y=y)$, is a weighted average of the $\mathrm{C}$ class-specific probabilities $\mathrm{P}(\mathrm{Y}=\mathrm{y} \mid \mathrm{X}=x)$; that is

$$
\mathrm{P}(\mathrm{Y}=\mathrm{y})=\sum_{\mathrm{X}=1}^{\mathrm{c}} \mathrm{P}(\mathrm{X}=\mathrm{x}) \mathrm{P}(\mathrm{Y}=\mathrm{y} \mid \mathrm{X}=x) .
$$

Here, $\mathrm{P}(\mathrm{X}=x)$ denotes the proportion of respondents that belong to latent class $x$ (Vermunt and Magidson 2000). (See Appendix for statistical details.) We estimated one-cluster models, then estimated two, three, and four-cluster models. We assessed model fit by comparing likelihood ratio chi-squared statistics $\left(\mathrm{L}_{2}\right)$, Bayes information criteria (BIC), and bivariate residuals. We find that a 5 cluster model provides the best fit to the data and report these results below.

Health trajectories. Next, we use LC cluster models to identify groups of respondents who are at most risk of poor health by examining their trajectories of self-reported poor and fair health between 1987/1988 and 2001/2002. After examining fit statistics, we conclude that a two-cluster model that groups together individuals who share similar trajectories of self-reported health provides the best fit to the data. Cluster 1 includes $70 \%$ of the sample who are unlikely to report poor health across waves, whereas members of Cluster $2(30 \%$ of the sample) are more likely to report fair/poor health across survey years. In fact, $80 \%$ of cluster 2 reports fair/poor health in Wave 3. Using Bayes' theorem (Vermunt and Magidson 2000), we sort each member of the sample into one of these two classes. LC models allow for the incorporation of covariates directly into the estimation of models, so we extend the model to include multiple sets of covariates to predict who is most likely to belong to the poor health trajectory.

\section{Results}

Educational trajectories. LC cluster models identify five common patterns of educational enrollment as respondents age. The largest identified cluster, representing $36 \%$ of the sample, have the lowest levels of educational attainment and school enrollment. We label this cluster the Non-attendees. The majority have completed 12 years of school or less, with a little more than half graduating from high school on time. Non-attendees tend to be older than other respondents and display the highest levels of poor health over time. 
They also display the lowest levels of economic resources in adulthood and weaker social bonds than other clusters.

Cluster 2, consisting of $20 \%$ of the sample, we label as the Technical Track. This group is 50 percent more likely than Non-attendees to graduate from high school and continue in adulthood to enroll in high school, vocational school, or junior college. Their levels of poor health are lower that Non-attendees and their economic and social resources higher, with the exception of their divorce rate, which is the highest of all clusters.

Clusters 3 and 4 represent two post-secondary academic trajectories. Seventeen percent of the sample is grouped in Cluster 3, which we label as the Junior College/University/Graduate track. Group members have relatively high levels of adult educational enrollment well into their 40s in four-year university and junior college settings. One in four completes the bachelor's degree on-time. Their economic and social resources are higher than the previous two clusters and their level of poor health across three waves is the lowest of the three. This cluster is also more highly represented by men than any other. Consisting of $15 \%$ of the full sample, Cluster 4 is the most educationally advantaged cluster in the study. We label this "fast track" cluster the University/Graduate track. Three-fourths complete their bachelor's degrees on time and one fourth complete graduate degrees on time. Their pattern of enrollment across age groups shows the high rate of early BA completion and relatively high rates of school enrollments until well into their 50s. They display the lowest rates of poor health across waves and better levels of economic and social resources.

Finally, Cluster 5 is labeled as Dabblers. This small group, only $12 \%$ of the sample, enrolls in diverse institutional programs across the life course. On-time high school graduation rates match those in the Technical Track cluster, but slightly more Dabblers go on to academic degrees. Their health patterns match those on the Technical Track, but their economic resources are more limited. Figures and tables further detailing all clusters are available on request.

Childhood background and educational trajectories. The impact of childhood background on allocation to the educational trajectories identified above is reported in Table 2. Parameter estimates from the latent class cluster analysis predict membership in school enrollment trajectories. Significant positive estimates predict membership in the identified cluster; significant negative numbers are predictive of non-membership. Overall, the results reveal a strong relationship between childhood background and movement along alternative educational trajectories. Disadvantaged childhood backgrounds are associated with the Non-attendee and Technical trajectories. Higher levels of poverty, single-parent households, low parental education, and fathers' lower occupational status predict placement on these tracks. Alternatively, childhood background measures significantly predict non-placement into the most advantaged academic track, the fast high-achieving track we label as University/Graduate. Placement into the slower academic track we label as Junior College/University/Graduate is predicted by only two childhood variables: father's SEI and disability/unemployment. A more advantaged childhood as measured by paternal employment facilitates membership in this cluster. Other predictors of trajectory membership are also consistent with expectations derived from cumulative advantage theory. Women are more likely to be selected into the Non-attendee trajectory. Hispanics 
Table 2: Covariate Parameter Estimates from Latent Class Cluster Analyses Predicting Membership in School Enrollment Trajectory; NSFH Waves 1, 2, and $3(\mathrm{~N}=3798)$

\begin{tabular}{|c|c|c|c|c|c|}
\hline & $\begin{array}{l}\text { Non- } \\
\text { Attendees }\end{array}$ & $\begin{array}{l}\text { Technical } \\
\text { Track }\end{array}$ & $\begin{array}{l}\text { JC/Univ/ } \\
\text { Grad Track }\end{array}$ & $\begin{array}{l}\text { University/ } \\
\text { Grad Track }\end{array}$ & Dabblers \\
\hline Intercept & $\begin{array}{r}-1.73^{*} \\
(0.29)\end{array}$ & $\begin{array}{r}1.40^{*} \\
(0.39)\end{array}$ & $\begin{array}{r}5.46^{*} \\
(0.48)\end{array}$ & $\begin{array}{c}3.26^{*} \\
(0.50)\end{array}$ & $\begin{array}{r}-8.39^{*} \\
(0.54)\end{array}$ \\
\hline Age & $\begin{array}{c}0.05^{*} \\
(0.01)\end{array}$ & $\begin{array}{r}-0.002^{*} \\
(0.005)\end{array}$ & $\begin{array}{r}-0.10^{*} \\
(0.01)\end{array}$ & $\begin{array}{r}-0.08^{*} \\
(0.01)\end{array}$ & $\begin{array}{c}0.13^{*} \\
(0.01)\end{array}$ \\
\hline Black & $\begin{array}{l}-0.10 \\
(0.06)\end{array}$ & $\begin{array}{c}0.02 \\
(0.06)\end{array}$ & $\begin{array}{c}0.04 \\
(0.07)\end{array}$ & $\begin{array}{r}0.003 \\
(0.08)\end{array}$ & $\begin{array}{c}0.04 \\
(0.10)\end{array}$ \\
\hline Hispanic & $\begin{array}{c}0.05 \\
(0.10)\end{array}$ & $\begin{array}{c}0.10 \\
(0.11)\end{array}$ & $\begin{array}{c}0.09 \\
(0.13)\end{array}$ & $\begin{array}{r}-0.34^{*} \\
(0.15)\end{array}$ & $\begin{array}{c}0.09 \\
(0.19)\end{array}$ \\
\hline Male & $\begin{array}{r}-0.22^{*} \\
(0.04)\end{array}$ & $\begin{array}{l}-0.03 \\
(0.04)\end{array}$ & $\begin{array}{r}0.18^{*} \\
(0.04)\end{array}$ & $\begin{array}{c}0.01 \\
(0.04)\end{array}$ & $\begin{array}{c}0.05 \\
(0.06)\end{array}$ \\
\hline Early public assistance & $\begin{array}{r}0.26^{*} \\
(0.07)\end{array}$ & $\begin{array}{c}0.28^{*} \\
(0.08)\end{array}$ & $\begin{array}{c}0.03 \\
(0.11)\end{array}$ & $\begin{array}{r}-0.42^{*} \\
(0.17)\end{array}$ & $\begin{array}{l}-0.15 \\
(0.14)\end{array}$ \\
\hline $\begin{array}{l}\text { Single-parent } \\
\text { household }\end{array}$ & $\begin{array}{r}0.09^{*} \\
(0.04)\end{array}$ & $\begin{array}{r}0.22^{*} \\
(0.05)\end{array}$ & $\begin{array}{c}-0.02 \\
(0.06)\end{array}$ & $\begin{array}{r}-0.28^{*} \\
(0.07)\end{array}$ & $\begin{array}{c}-0.02 \\
(0.08)\end{array}$ \\
\hline $\begin{array}{l}\text { Number of siblings } \\
\text { in hh }\end{array}$ & $\begin{array}{r}0.14^{*} \\
(0.01)\end{array}$ & $\begin{array}{r}0.09^{*} \\
(0.02)\end{array}$ & $\begin{array}{c}-0.02 \\
(0.02)\end{array}$ & $\begin{array}{r}-0.09^{*} \\
(0.02)\end{array}$ & $\begin{array}{l}-0.12 \\
(0.03)\end{array}$ \\
\hline $\begin{array}{l}\text { Mom no high school } \\
\text { degree }\end{array}$ & $\begin{array}{r}0.14^{*} \\
(0.04)\end{array}$ & $\begin{array}{r}0.14^{*} \\
(0.05)\end{array}$ & $\begin{array}{c}-0.04 \\
(0.05)\end{array}$ & $\begin{array}{r}-0.21^{*} \\
(0.06)\end{array}$ & $\begin{array}{l}-0.03 \\
(0.07)\end{array}$ \\
\hline $\begin{array}{l}\text { Dad no high school } \\
\text { degree }\end{array}$ & $\begin{array}{r}0.08^{*} \\
(0.04)\end{array}$ & $\begin{array}{r}0.09^{*} \\
(0.04)\end{array}$ & $\begin{array}{c}-0.09 \\
(0.05)\end{array}$ & $\begin{array}{c}-0.18^{*} \\
(0.06)\end{array}$ & $\begin{array}{c}0.11 \\
(0.07)\end{array}$ \\
\hline Dad occupation SEI & $\begin{array}{r}-2.07^{*} \\
(0.22)\end{array}$ & $\begin{array}{r}-1.63^{*} \\
(0.26)\end{array}$ & $\begin{array}{r}0.61^{*} \\
(0.24)\end{array}$ & $\begin{array}{r}1.59^{*} \\
(0.23)\end{array}$ & $\begin{array}{r}1.51^{*} \\
(0.31)\end{array}$ \\
\hline $\begin{array}{l}\text { Dad disabled/ } \\
\text { unemployed }\end{array}$ & $\begin{array}{c}0.09 \\
(0.14)\end{array}$ & $\begin{array}{c}0.01 \\
(0.06)\end{array}$ & $\begin{array}{r}-0.30^{*} \\
(0.13)\end{array}$ & $\begin{array}{r}-0.16^{*} \\
(0.04)\end{array}$ & $\begin{array}{c}0.36^{*} \\
(0.15)\end{array}$ \\
\hline$\overline{\mathrm{BIC}}$ & 53012.41 & & & & \\
\hline Log likelihood & -25381.14 & & & & \\
\hline Covariate $\mathrm{R}^{2}$ & 0.68 & & & & \\
\hline
\end{tabular}

${ }^{*} \mathrm{p}<.01$

are less likely than Blacks or Whites to follow the most advantaged track. The Dabblers are perhaps the most heterogeneous cluster. They are older and come from mixed childhood backgrounds.

Health trajectories. Figure 2 depicts the probability of self-reported poor or fair health for the full sample, by gender, and by LC cluster membership. First, Fig. 2 reveals heterogeneity in health trajectories that is lost by simply looking at full sample averages. The model identifies two distinct groups of respondents, those at high risk of poor health and those at low risk. Nearly one in five women and men are selected into the poor health trajectory, with women having a higher average probability of poor health at all time points. Men and women clustered in the good health trajectories experience low (less than 10\% risk) but increasing chances of reporting poor health over time. Although men and women 


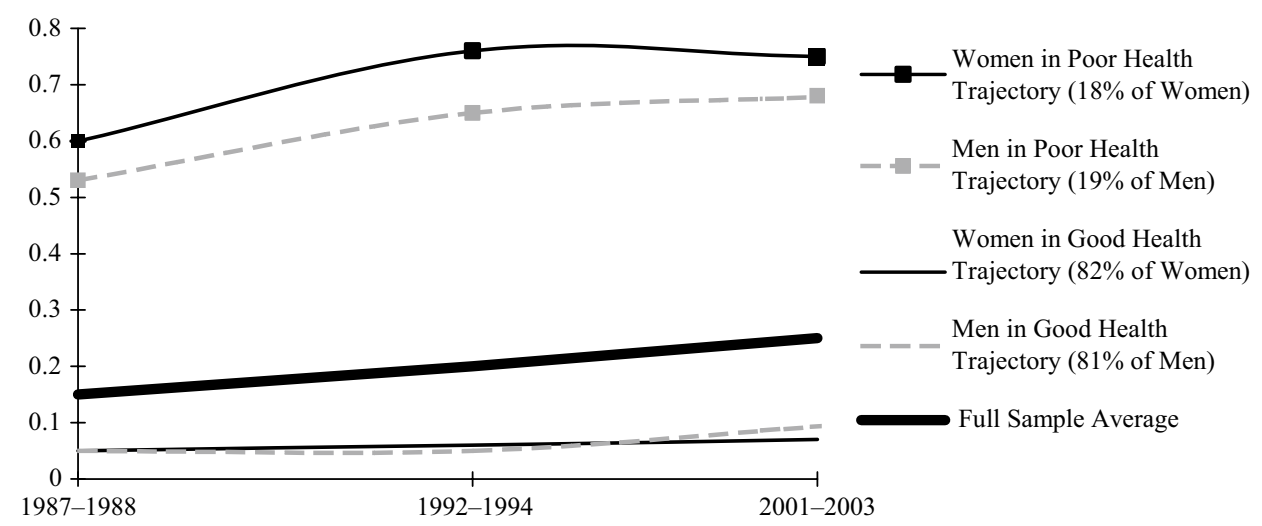

Fig. 2: Probability of Self-Reported Poor or Fair Health for Full NSFH Sample, by LC Cluster and by Gender; $\mathrm{N}=3798$

in the good health trajectory experience the same risk of poor health during the first wave, women experience a slight health advantage 14 years later.

Interdependence of educational and adult health trajectories. The second objective of this study is to deal explicitly with the interdependence of educational trajectories and health trajectories. How interrelated are these two trajectories? What are the temporal factors that underlie their association? Table 3 reports two sets of predicted probabilities, one predicting educational trajectory conditional on the poor health trajectory and the second predicting placement in the poor health trajectory conditional on educational trajectory. The estimates are almost mirror images of each other. Also, the probability estimates indicate that the Non-attendee trajectory is the most strongly associated with the poor adult health trajectory. The other four educational trajectories are significantly less likely to fall into poor health with the most advantaged academic track the least likely.

Table 3: Linkages between Health and Education Trajectories; NSFH Waves 1, 2, and 3

\section{Predicted Probability of Poor Health Trajectory Conditional on School Enrollment} Trajectory

$\begin{array}{ll}\text { Cluster 1: Non-School Attendees } & 0.54 \\ \text { Cluster 2: Technical Track } & 0.19 \\ \text { Cluster 3: Junior College/University/Grad School Track } & 0.10 \\ \text { Cluster 4: On-Time and Late University/Grad School Track } & 0.07 \\ \text { Cluster 5: Dabblers } & 0.11\end{array}$

Predicted Probability of School Enrollment Trajectory Conditional on Poor Health Trajectory
Cluster 1: Non-School Attendees
Cluster 2: Technical Track
0.18
Cluster 3: Junior College/University/Grad School Track
Cluster 4: On-Time and Late University/Grad School Track
0.08
Cluster 5: Dabblers
0.11 
Table 4: Fit Statistics from Latent Class Cluster Models Using Alternative Measures of Education as Predictors of Membership in Poor Health Trajectory, Controlling for Age and Race/Ethnicity; NSFH Waves 1, 2, and 3

\begin{tabular}{|c|c|c|c|c|}
\hline \multirow[b]{2}{*}{ Measure of Education } & \multicolumn{2}{|c|}{ Women } & \multicolumn{2}{|l|}{ Men } \\
\hline & $\overline{\mathbf{R}^{2}}$ & BIC & $\mathbf{R}^{2}$ & BIC \\
\hline Degree completion & 0.07 & 6806.15 & 0.08 & 3868.88 \\
\hline Enrollment trajectory & 0.09 & 6787.32 & 0.09 & 3860.22 \\
\hline Years of completed schooling & 0.12 & 6715.91 & 0.11 & 3822.96 \\
\hline $\begin{array}{l}\text { Years of schooling + enrollment } \\
\text { trajectory }\end{array}$ & 0.12 & 6746.16 & 0.11 & 3848.97 \\
\hline Timing of degree completion & 0.15 & 6721.38 & 0.12 & 3854.90 \\
\hline $\begin{array}{l}\text { Timing of degree completion }+ \text { years } \\
\text { of schooling }\end{array}$ & 0.15 & 6721.92 & 0.12 & 3859.30 \\
\hline $\begin{array}{l}\text { Enrollment trajectory }+ \text { timing } \\
\text { of degree completion }\end{array}$ & 0.16 & 6717.57 & 0.12 & 3879.96 \\
\hline
\end{tabular}

We are also interested in the temporal and track characteristics of these trajectories as predictors of poor health. Table 4 parameterizes education seven ways to unpack the components of educational careers and their relative impact on poor health, controlling for key demographic variables. This analysis tests which of the following aspects of education are most strongly related to health trajectories: number of years of completed schooling (point-in-time attainment), age and enrollment patterns in various types of schools (pathway to attainment), degree completion (credentialing effect), or age of degree completion (age of credentialing). Table 4 reports fit statistics from LC cluster models using seven combinations of these components of educational careers to predict placement in the poor health trajectory, controlling for key age, race/ethnicity, and gender. Timing of degree completion and years of schooling stand out as the most predictive when taken singly. Although timing of degree completion combined with years of schooling has strong predictive power, the results point to the greatest relative importance of the combination of timing of degree completion and placement in enrollment trajectory for predicting poor health compared to the other six components. Overall, the timing of completion variable improves fit for both men and women, but the trajectory and timing variables fit women's patterns better.

Our argument here is twofold. First, following cumulative advantage theory, timing is important. Early degree completion initiates a more advantaged adult pathway leading to better health. Second, the best fitting combination also provides more information about the educational career. Besides timing, the enrollment track tells us more about the kinds of education being acquired over time, and often at the same time, as health patterns are also emerging. We know from earlier estimates that Non-attendees are at highest risk for poor health across three waves of observation. The significant differences by gender in these patterns will be examined below in full models predicting fair/poor health trajectories separately by gender.

Anchoring and persistent effects of childhood conditions on adult health. Tables 5 and 6 show results from the full LC models of the relationship between childhood conditions, 
Table 5: Parameter Estimates and Standard Errors Predicting Women's Membership in Poor Health Trajectory from Latent Class Cluster Model; NSFH Waves 1, 2, and $3(\mathrm{~N}=2407)$

\begin{tabular}{|c|c|c|c|c|c|c|}
\hline & Model 1 & Model 2 & Model 3 & Model 4 & Model 5 & Model 6 \\
\hline \multicolumn{7}{|c|}{ Demographics and Family Background Covariates: } \\
\hline Age & $\begin{array}{l}0.01^{* * *} \\
(0.002)\end{array}$ & $\begin{array}{r}0.006^{*} \\
(0.003)\end{array}$ & $\begin{array}{c}-0.003 \\
(0.003)\end{array}$ & $\begin{array}{c}-0.003 \\
(0.004)\end{array}$ & $\begin{array}{l}-0.001 \\
(0.004)\end{array}$ & $\begin{array}{l}-0.001 \\
(0.004)\end{array}$ \\
\hline Black & $\begin{array}{l}0.17^{* * *} \\
(0.04)\end{array}$ & $\begin{array}{l}0.17^{* * *} \\
(0.04)\end{array}$ & $\begin{array}{l}0.16^{* * *} \\
(0.05)\end{array}$ & $\begin{array}{l}0.14^{* * *} \\
(0.05)\end{array}$ & $\begin{array}{r}0.09^{*} \\
(0.04)\end{array}$ & $\begin{array}{r}0.14^{*} \\
(0.06)\end{array}$ \\
\hline Hispanic & $\begin{array}{l}0.30^{* * *} \\
(0.07)\end{array}$ & $\begin{array}{l}0.27^{* * *} \\
(0.07)\end{array}$ & $\begin{array}{l}0.30^{* * *} \\
(0.08)\end{array}$ & $\begin{array}{l}0.29^{* * *} \\
(0.08)\end{array}$ & $\begin{array}{l}0.26^{* * *} \\
(0.09)\end{array}$ & $\begin{array}{l}0.33^{* * *} \\
(0.09)\end{array}$ \\
\hline $\begin{array}{l}\text { Public } \\
\text { assistance }\end{array}$ & $\begin{array}{l}0.17^{* * *} \\
(0.05)\end{array}$ & $\begin{array}{l}0.15^{* * *} \\
(0.05)\end{array}$ & $\begin{array}{r}0.12^{*} \\
(0.05)\end{array}$ & $\begin{array}{r}0.13^{*} \\
(0.05)\end{array}$ & $\begin{array}{l}0.13^{*} \\
(0.06)\end{array}$ & $\begin{array}{c}0.11^{*} \\
(0.05)\end{array}$ \\
\hline $\begin{array}{l}\text { Single } \\
\text { parent hh }\end{array}$ & $\begin{array}{r}0.08^{*} \\
(0.03)\end{array}$ & $\begin{array}{c}0.08^{*} \\
(0.04)\end{array}$ & $\begin{array}{r}0.08^{*} \\
(0.04)\end{array}$ & $\begin{array}{r}0.04^{*} \\
(0.02)\end{array}$ & $\begin{array}{r}0.04^{*} \\
(0.02)\end{array}$ & $\begin{array}{r}0.06^{*} \\
(0.03)\end{array}$ \\
\hline $\begin{array}{l}\text { Number } \\
\text { siblings in hh }\end{array}$ & $\begin{array}{l}0.03^{* *} \\
(0.01)\end{array}$ & $\begin{array}{r}0.02^{*} \\
(0.01)\end{array}$ & $\begin{array}{c}0.01 \\
(0.01)\end{array}$ & $\begin{array}{c}0.01 \\
(0.01)\end{array}$ & $\begin{array}{c}0.01 \\
(0.01)\end{array}$ & $\begin{array}{c}0.02 \\
(0.02)\end{array}$ \\
\hline $\begin{array}{l}\text { Mom } \\
\text { years }\end{array}$ & $\begin{array}{r}0.04^{*} \\
(0.02)\end{array}$ & $\begin{array}{c}0.02 \\
(0.03)\end{array}$ & $\begin{array}{c}0.03 \\
(0.02)\end{array}$ & $\begin{array}{c}0.02 \\
(0.03)\end{array}$ & $\begin{array}{c}0.04 \\
(0.04)\end{array}$ & $\begin{array}{c}0.01 \\
(0.04)\end{array}$ \\
\hline $\begin{array}{l}\mathrm{Dad}<12 \\
\text { years school }\end{array}$ & $\begin{array}{c}0.04^{*} \\
(0.02)\end{array}$ & $\begin{array}{c}0.03 \\
(0.03)\end{array}$ & $\begin{array}{c}0.04 \\
(0.04)\end{array}$ & $\begin{array}{c}0.02 \\
(0.04)\end{array}$ & $\begin{array}{c}0.02 \\
(0.04)\end{array}$ & $\begin{array}{c}0.01 \\
(0.04)\end{array}$ \\
\hline $\begin{array}{l}\text { Dad occupa- } \\
\text { tional SEI }\end{array}$ & $\begin{array}{l}-0.52^{* * *} \\
(0.18)\end{array}$ & $\begin{array}{l}-0.31^{* *} \\
(0.12)\end{array}$ & $\begin{array}{l}-0.28^{*} \\
(0.14)\end{array}$ & $\begin{array}{l}-0.23^{*} \\
(0.12)\end{array}$ & $\begin{array}{l}-0.22 \\
(0.17)\end{array}$ & $\begin{array}{l}-0.06 \\
(0.25)\end{array}$ \\
\hline $\begin{array}{l}\text { Dad } \\
\text { unemployed }\end{array}$ & $\begin{array}{l}0.19^{* *} \\
(0.05)\end{array}$ & $\begin{array}{c}0.11 \\
(0.09)\end{array}$ & $\begin{array}{c}0.13 \\
(0.12)\end{array}$ & $\begin{array}{c}0.11 \\
(0.11)\end{array}$ & $\begin{array}{c}0.13 \\
(0.12)\end{array}$ & $\begin{array}{c}0.06 \\
(0.14)\end{array}$ \\
\hline \multicolumn{7}{|c|}{ School Enrollment Trajectory ${ }^{1}$ : } \\
\hline $\begin{array}{l}\text { Techn } \\
\text { track }\end{array}$ & - & $\begin{array}{l}-0.12^{* *} \\
(0.05)\end{array}$ & $\begin{array}{l}-0.06 \\
(0.05)\end{array}$ & $\begin{array}{l}-0.04 \\
(0.05)\end{array}$ & $\begin{array}{l}-0.02 \\
(0.06)\end{array}$ & $\begin{array}{l}-0.03 \\
(0.06)\end{array}$ \\
\hline $\begin{array}{l}\text { J. college/ } \\
\text { university/grad }\end{array}$ & - & $\begin{array}{l}-0.35^{* * *} \\
(0.07)\end{array}$ & $\begin{array}{l}-0.23^{* * *} \\
(0.08)\end{array}$ & $\begin{array}{l}-0.20^{* *} \\
(0.08)\end{array}$ & $\begin{array}{l}-0.13^{*} \\
(0.06)\end{array}$ & $\begin{array}{l}-0.08 \\
(0.09)\end{array}$ \\
\hline $\begin{array}{l}\text { University/ } \\
\text { grad }\end{array}$ & - & $\begin{array}{l}-0.31^{* * *} \\
(0.07)\end{array}$ & $\begin{array}{l}-0.19^{* * *} \\
(0.07)\end{array}$ & $\begin{array}{l}-0.16^{* *} \\
(0.07)\end{array}$ & $\begin{array}{l}-0.16^{*} \\
(0.07)\end{array}$ & $\begin{array}{l}-0.08 \\
(0.08)\end{array}$ \\
\hline Dabbler & - & $\begin{array}{l}-0.17^{* * *} \\
(0.05)\end{array}$ & $\begin{array}{l}-0.14^{* *} \\
(0.05)\end{array}$ & $\begin{array}{l}-0.11^{*} \\
(0.05)\end{array}$ & $\begin{array}{l}-0.12^{*} \\
(0.06)\end{array}$ & $\begin{array}{l}-0.07 \\
(0.07)\end{array}$ \\
\hline \multicolumn{7}{|c|}{ Degree Completion and Timing: } \\
\hline $\begin{array}{l}\text { High school } \\
\text { degree }\end{array}$ & - & $\begin{array}{l}-0.17^{* * *} \\
(0.04)\end{array}$ & $\begin{array}{l}-0.12^{* * *} \\
(0.04)\end{array}$ & $\begin{array}{l}-0.10^{* *} \\
(0.04)\end{array}$ & $\begin{array}{l}-0.11^{* *} \\
(0.04)\end{array}$ & $\begin{array}{l}-0.11^{*} \\
(0.05)\end{array}$ \\
\hline $\begin{array}{l}\text { Associate's } \\
\text { degree }\end{array}$ & - & $\begin{array}{l}-0.14^{*} \\
(0.07)\end{array}$ & $\begin{array}{l}-0.12^{*} \\
(0.06)\end{array}$ & $\begin{array}{l}-0.15^{*} \\
(0.07)\end{array}$ & $\begin{array}{l}-0.11^{*} \\
(0.05)\end{array}$ & $\begin{array}{l}-0.10^{*} \\
(0.05)\end{array}$ \\
\hline $\begin{array}{l}\text { Bachelor's } \\
\text { degree }\end{array}$ & - & $\begin{array}{l}-0.21^{* * *} \\
(0.07)\end{array}$ & $\begin{array}{l}-0.18^{*} \\
(0.08)\end{array}$ & $\begin{array}{l}-0.16^{*} \\
(0.08)\end{array}$ & $\begin{array}{l}-0.16^{*} \\
(0.07)\end{array}$ & $\begin{array}{l}-0.14^{*} \\
(0.06)\end{array}$ \\
\hline
\end{tabular}


Table 5: (continued)

\begin{tabular}{|c|c|c|c|c|c|c|}
\hline & Model 1 & Model 2 & Model 3 & Model 4 & Model 5 & Model 6 \\
\hline $\begin{array}{l}\text { Graduate } \\
\text { degree }\end{array}$ & - & $\begin{array}{l}-0.08 \\
(0.10)\end{array}$ & $\begin{array}{l}-0.05 \\
(0.10)\end{array}$ & $\begin{array}{l}-0.03 \\
(0.11)\end{array}$ & $\begin{array}{l}-0.02 \\
(0.11)\end{array}$ & $\begin{array}{l}-0.10 \\
(0.12)\end{array}$ \\
\hline Late degree & - & $\begin{array}{r}0.07^{*} \\
(0.03)\end{array}$ & $\begin{array}{l}0.12^{* * *} \\
(0.04)\end{array}$ & $\begin{array}{l}0.11^{* * *} \\
(0.04)\end{array}$ & $\begin{array}{r}0.08^{*} \\
(0.04)\end{array}$ & $\begin{array}{r}0.10^{*} \\
(0.05)\end{array}$ \\
\hline \multicolumn{7}{|c|}{ Employment and Economic Resources: } \\
\hline Employed & - & - & $\begin{array}{l}-0.27^{* * *} \\
(0.04)\end{array}$ & $\begin{array}{l}-0.28^{* * *} \\
(0.04)\end{array}$ & $\begin{array}{l}-0.28^{* * *} \\
(0.05)\end{array}$ & $\begin{array}{l}-0.25^{* * *} \\
(0.05)\end{array}$ \\
\hline $\begin{array}{l}\text { Manager/pro- } \\
\text { fessional }\end{array}$ & - & - & $\begin{array}{l}-0.14^{* *} \\
(0.05)\end{array}$ & $\begin{array}{l}-0.09^{*} \\
(0.05)\end{array}$ & $\begin{array}{c}-0.08 \\
(0.06)\end{array}$ & $\begin{array}{l}-0.07 \\
(0.06)\end{array}$ \\
\hline $\begin{array}{l}\text { Household } \\
\text { income (ln) }\end{array}$ & - & - & $\begin{array}{c}0.01 \\
(0.01)\end{array}$ & $\begin{array}{c}0.01 \\
(0.01)\end{array}$ & $\begin{array}{c}0.01 \\
(0.01)\end{array}$ & $\begin{array}{c}0.02 \\
(0.01)\end{array}$ \\
\hline $\begin{array}{l}\text { Worry about } \\
\text { income }\end{array}$ & - & - & $\begin{array}{l}0.29^{* * * *} \\
(0.04)\end{array}$ & $\begin{array}{l}0.26^{* * *} \\
(0.04)\end{array}$ & $\begin{array}{l}0.21^{* * *} \\
(0.04)\end{array}$ & $\begin{array}{r}0.10^{*} \\
(0.05)\end{array}$ \\
\hline $\begin{array}{l}\text { Has health } \\
\text { insurance }\end{array}$ & - & - & $\begin{array}{l}-0.20^{* * * *} \\
(0.04)\end{array}$ & $\begin{array}{c}-0.17^{* * *} \\
(0.04)\end{array}$ & $\begin{array}{l}-0.13^{* * *} \\
(0.04)\end{array}$ & $\begin{array}{l}-0.13^{* *} \\
(0.05)\end{array}$ \\
\hline \multicolumn{7}{|l|}{ Social Ties: } \\
\hline $\begin{array}{l}\text { Number chil- } \\
\text { dren birthed }\end{array}$ & - & - & - & $\begin{array}{l}0.05^{* * *} \\
(0.01)\end{array}$ & $\begin{array}{r}0.04^{*} \\
(0.02)\end{array}$ & $\begin{array}{r}0.04^{*} \\
(0.02)\end{array}$ \\
\hline Ever divorced & - & - & - & $\begin{array}{l}0.11^{* * *} \\
(0.03)\end{array}$ & $\begin{array}{l}0.12^{* * *} \\
(0.04)\end{array}$ & $\begin{array}{l}0.09^{* *} \\
(0.04)\end{array}$ \\
\hline $\begin{array}{l}\text { Difficult } \\
\text { relationships }\end{array}$ & - & - & - & $\begin{array}{l}0.20^{* * *} \\
(0.04)\end{array}$ & $\begin{array}{l}0.21^{* * *} \\
(0.05)\end{array}$ & $\begin{array}{r}0.09^{*} \\
(0.04)\end{array}$ \\
\hline $\begin{array}{l}\text { No socializing } \\
\text { w/friends }\end{array}$ & - & - & - & $\begin{array}{r}0.05^{*} \\
(0.02)\end{array}$ & $\begin{array}{c}0.04 \\
(0.04)\end{array}$ & $\begin{array}{c}0.02 \\
(0.04)\end{array}$ \\
\hline \multicolumn{7}{|l|}{ Health Behaviors ${ }^{3}$ : } \\
\hline Non-drinker & - & - & - & - & $\begin{array}{l}0.25^{* * *} \\
(0.04)\end{array}$ & $\begin{array}{l}0.24^{* * *} \\
(0.05)\end{array}$ \\
\hline Heavy drinker & - & - & - & - & $\begin{array}{c}0.01 \\
(0.11)\end{array}$ & $\begin{array}{c}0.02 \\
(0.12)\end{array}$ \\
\hline $\begin{array}{l}\text { Current } \\
\text { smoker }\end{array}$ & - & - & - & - & $\begin{array}{r}0.11^{*} \\
(0.05)\end{array}$ & $\begin{array}{r}0.14^{*} \\
(0.06)\end{array}$ \\
\hline Ever smoked & - & - & - & - & $\begin{array}{r}0.04^{*} \\
(0.04)\end{array}$ & $\begin{array}{r}0.05^{*} \\
(0.02)\end{array}$ \\
\hline Obese & - & - & - & - & $\begin{array}{l}0.30^{* * *} \\
(0.04)\end{array}$ & $\begin{array}{l}0.30^{* * *} \\
(0.04)\end{array}$ \\
\hline \multicolumn{7}{|c|}{ Psychological Resources: } \\
\hline $\begin{array}{l}\text { Personal } \\
\text { control }\end{array}$ & - & - & - & - & - & $\begin{array}{l}-0.08^{* * *} \\
(0.02)\end{array}$ \\
\hline Competency & - & - & - & - & - & $\begin{array}{l}-0.21^{* * *} \\
(0.03)\end{array}$ \\
\hline
\end{tabular}


Table 5: (continued)

\begin{tabular}{lrrrrrr}
\hline & Model 1 & Model 2 & Model 3 & Model 4 & Model 5 & Model 6 \\
\hline Direct Effects: & & & & & & \\
Poor health & $0.32^{* * *}$ & $0.30^{* * *}$ & $0.30^{* * *}$ & $0.29^{* * *}$ & $0.28^{* * *}$ & \multicolumn{1}{c}{$0.26^{* * *}$} \\
W1 \& W2 & $(0.04)$ & $(0.03)$ & $(0.04)$ & $(0.04)$ & $(0.04)$ & $(0.04)$ \\
Log & -3339.05 & -3303.57 & -3205.48 & -3183.32 & -3131.55 & -3025.83 \\
likelihood & & & & & & \\
BIC & 6818.25 & 6817.36 & 6660.12 & 6646.94 & 6582.33 & 6386.18 \\
Covariate $\mathrm{R}^{2}$ & 0.10 & 0.13 & 0.23 & 0.26 & 0.32 & 0.39 \\
\hline
\end{tabular}

" $\mathrm{p}<.05,{ }^{* *} \mathrm{p}<.01,{ }^{* * *} \mathrm{p}<.001$

${ }^{1}$ Omitted reference category is non-school attendee cluster.

${ }^{2}$ Omitted reference categories are no high school degree versus the included degrees and ontime degree versus late degree.

${ }^{3}$ Omitted reference categories are moderate drinkers, never smoked, and not obese.

educational trajectories and adult health. The gender-specific results are largely consistent with our theoretical perspective. Table 5 reports nested models predicting poor health trajectory with covariates among women. First, demographic and selected childhood background variables reveal remarkably persistent effects on poor health trajectories after controlling for components of educational trajectories, employment, and economic resources, social ties, health behaviors, and psychological resources (Models 1-6). Race/ ethnic effects are consistent with general patterns already observed across studies. Black and Hispanic women are at higher risks for poor health. Among childhood conditions, public assistance and single parent household persist in their impacts on later health. The effects of any other childhood characteristics disappear permanently after components of educational careers are introduced in Model 2.

Second, the effects of school enrollment trajectories reveal the strong association between the Non-attendee cluster (the reference category) and poor health. The four other trajectories are less likely to fall into the poor health trajectory, with the two academic tracks the least likely compared to cluster 1. Credentials and timing also matter in the multivariate context. Those without high school diplomas are significantly more like to fall into poor health than those in all credential categories. Those with BA degrees are least likely to fall into poor health. Among those attaining degrees, those who are late in gaining their highest credential are more likely to report poor health than those who are on time.

Third, the remaining models add additional covariates related to economic, social, and personal behaviors and resources. Lower economic resources, weaker social ties, risky health behaviors, and lower psychological resources increase the likelihood of falling into the poor health trajectory, net of the significant contributions of childhood and educational backgrounds.

Table 6 reports results from the same models for men. Clear gender differences are apparent. First, childhood conditions diminish and then disappear in their effects on men's health with the introduction of adult social variables. Among the educational trajectory variables, the only persistent differentiating effects are those in the reduction of poor health by graduate degree completion — neither the fast track college-grad trajectory 
Table 6: Parameter Estimates and Standard Errors Predicting Men's Membership in Poor Health Trajectory from Latent Class Cluster Model; NSFH Waves 1, 2, and $3(\mathrm{~N}=1391)$

\begin{tabular}{|c|c|c|c|c|c|c|}
\hline & Model 1 & Model 2 & Model 3 & Model 4 & Model 5 & Model 6 \\
\hline \multicolumn{7}{|c|}{ Demographics and Family Background Covariates: } \\
\hline Age & $\begin{array}{l}0.01^{* *} \\
(0.004)\end{array}$ & $\begin{array}{c}0.001^{* *} \\
(0.004)\end{array}$ & $\begin{array}{c}0.003 \\
(0.006)\end{array}$ & $\begin{array}{l}0.01 \\
(0.01)\end{array}$ & $\begin{array}{c}0.01 \\
(0.01)\end{array}$ & $\begin{array}{c}0.01 \\
(0.01)\end{array}$ \\
\hline Black & $\begin{array}{r}0.12^{*} \\
(0.06)\end{array}$ & $\begin{array}{c}0.10 \\
(0.06)\end{array}$ & $\begin{array}{c}0.05 \\
(0.07)\end{array}$ & $\begin{array}{c}0.04 \\
(0.07)\end{array}$ & $\begin{array}{c}0.04 \\
(0.07)\end{array}$ & $\begin{array}{c}0.02 \\
(0.08)\end{array}$ \\
\hline Hispanic & $\begin{array}{c}0.12 \\
(0.07)\end{array}$ & $\begin{array}{c}0.08 \\
(0.10)\end{array}$ & $\begin{array}{c}0.04 \\
(0.12)\end{array}$ & $\begin{array}{c}0.04 \\
(0.12)\end{array}$ & $\begin{array}{c}0.09 \\
(0.13)\end{array}$ & $\begin{array}{c}0.09 \\
(0.15)\end{array}$ \\
\hline Public assistance & $\begin{array}{c}0.07 \\
(0.08)\end{array}$ & $\begin{array}{c}0.08 \\
(0.08)\end{array}$ & $\begin{array}{c}0.06 \\
(0.08)\end{array}$ & $\begin{array}{c}0.08 \\
(0.08)\end{array}$ & $\begin{array}{c}0.14 \\
(0.09)\end{array}$ & $\begin{array}{c}0.10 \\
(0.10)\end{array}$ \\
\hline Single parent hh & $\begin{array}{l}0.14^{* *} \\
(0.05)\end{array}$ & $\begin{array}{r}0.10^{*} \\
(0.05)\end{array}$ & $\begin{array}{r}0.10^{*} \\
(0.05)\end{array}$ & $\begin{array}{r}0.11^{*} \\
(0.05)\end{array}$ & $\begin{array}{r}0.11^{*} \\
(0.05)\end{array}$ & $\begin{array}{c}0.07 \\
(0.07)\end{array}$ \\
\hline $\begin{array}{l}\text { Number siblings } \\
\text { in } \mathrm{hh}\end{array}$ & $\begin{array}{l}0.04^{* *} \\
(0.01)\end{array}$ & $\begin{array}{c}0.02 \\
(0.02)\end{array}$ & $\begin{array}{c}0.02 \\
(0.02)\end{array}$ & $\begin{array}{c}0.01 \\
(0.01)\end{array}$ & $\begin{array}{c}0.01 \\
(0.02)\end{array}$ & $\begin{array}{c}0.02 \\
(0.02)\end{array}$ \\
\hline $\begin{array}{l}\text { Mom }<12 \text { years } \\
\text { school }\end{array}$ & $\begin{array}{c}0.06 \\
(0.04)\end{array}$ & $\begin{array}{c}0.04 \\
(0.05)\end{array}$ & $\begin{array}{c}0.05 \\
(0.05)\end{array}$ & $\begin{array}{c}0.06 \\
(0.05)\end{array}$ & $\begin{array}{c}0.07 \\
(0.06)\end{array}$ & $\begin{array}{c}0.09 \\
(0.06)\end{array}$ \\
\hline $\begin{array}{l}\text { Dad }<12 \text { years } \\
\text { school }\end{array}$ & $\begin{array}{c}0.06 \\
(0.04)\end{array}$ & $\begin{array}{c}0.03 \\
(0.05)\end{array}$ & $\begin{array}{c}0.02 \\
(0.05)\end{array}$ & $\begin{array}{c}0.02 \\
(0.05)\end{array}$ & $\begin{array}{c}0.01 \\
(0.05)\end{array}$ & $\begin{array}{c}0.04 \\
(0.06)\end{array}$ \\
\hline $\begin{array}{l}\text { Dad occupa- } \\
\text { tional SEI }\end{array}$ & $\begin{array}{l}-0.16 \\
(0.23)\end{array}$ & $\begin{array}{l}-0.27 \\
(0.25)\end{array}$ & $\begin{array}{l}-0.32 \\
(0.28)\end{array}$ & $\begin{array}{l}-0.32 \\
(0.27)\end{array}$ & $\begin{array}{l}-0.44 \\
(0.29)\end{array}$ & $\begin{array}{c}-0.42 \\
(0.34)\end{array}$ \\
\hline Dad unemployed & $\begin{array}{c}0.20 \\
(0.15)\end{array}$ & $\begin{array}{c}0.22 \\
(0.17)\end{array}$ & $\begin{array}{c}0.17 \\
(0.18)\end{array}$ & $\begin{array}{c}0.20 \\
(0.18)\end{array}$ & $\begin{array}{c}0.13 \\
(0.18)\end{array}$ & $\begin{array}{c}0.25 \\
(0.21)\end{array}$ \\
\hline \multicolumn{7}{|c|}{ School Enrollment Trajectory ${ }^{1}$ : } \\
\hline Technical track & - & $\begin{array}{l}-0.10^{*} \\
(0.05)\end{array}$ & $\begin{array}{l}-0.05 \\
(0.07)\end{array}$ & $\begin{array}{l}-0.04 \\
(0.07)\end{array}$ & $\begin{array}{l}-0.08 \\
(0.08)\end{array}$ & $\begin{array}{c}-0.01 \\
(0.09)\end{array}$ \\
\hline $\begin{array}{l}\text { J. college/ } \\
\text { university/grad }\end{array}$ & - & $\begin{array}{l}-0.25^{* * *} \\
(0.08)\end{array}$ & $\begin{array}{l}-0.11 \\
(0.09)\end{array}$ & $\begin{array}{l}-0.10 \\
(0.08)\end{array}$ & $\begin{array}{l}-0.08 \\
(0.09)\end{array}$ & $\begin{array}{c}0.01 \\
(0.11)\end{array}$ \\
\hline University/grad & - & $\begin{array}{l}-0.34^{* * *} \\
(0.09)\end{array}$ & $\begin{array}{l}-0.20^{*} \\
(0.09)\end{array}$ & $\begin{array}{l}-0.19^{* *} \\
(0.09)\end{array}$ & $\begin{array}{r}-0.15^{*} \\
(0.07)\end{array}$ & $\begin{array}{l}-0.08 \\
(0.12)\end{array}$ \\
\hline Dabbler & - & $\begin{array}{l}-0.19^{* * *} \\
(0.07)\end{array}$ & $\begin{array}{l}-0.21^{* *} \\
(0.07)\end{array}$ & $\begin{array}{l}-0.21^{* *} \\
(0.07)\end{array}$ & $\begin{array}{l}-0.18^{*} \\
(0.08)\end{array}$ & $\begin{array}{l}-0.10 \\
(0.09)\end{array}$ \\
\hline \multicolumn{7}{|c|}{ Degree Completion and Timing ${ }^{2}$ : } \\
\hline $\begin{array}{l}\text { High school } \\
\text { degree }\end{array}$ & - & $\begin{array}{l}-0.13^{* *} \\
(0.05)\end{array}$ & $\begin{array}{l}-0.09 \\
(0.06)\end{array}$ & $\begin{array}{l}-0.09 \\
(0.06)\end{array}$ & $\begin{array}{l}-0.10 \\
(0.06)\end{array}$ & $\begin{array}{l}-0.11 \\
(0.07)\end{array}$ \\
\hline $\begin{array}{l}\text { Associate's } \\
\text { degree }\end{array}$ & - & $\begin{array}{l}-0.02 \\
(0.08)\end{array}$ & $\begin{array}{l}-0.03 \\
(0.09)\end{array}$ & $\begin{array}{l}-0.03 \\
(0.09)\end{array}$ & $\begin{array}{l}-0.01 \\
(0.10)\end{array}$ & $\begin{array}{c}-0.05 \\
(0.11)\end{array}$ \\
\hline $\begin{array}{l}\text { Bachelor's } \\
\text { degree }\end{array}$ & - & $\begin{array}{l}-0.08 \\
(0.07)\end{array}$ & $\begin{array}{l}-0.05 \\
(0.08)\end{array}$ & $\begin{array}{l}-0.04 \\
(0.08)\end{array}$ & $\begin{array}{l}-0.01 \\
(0.08)\end{array}$ & $\begin{array}{c}-0.06 \\
(0.10)\end{array}$ \\
\hline Graduate degree & - & $\begin{array}{l}-0.37^{* * *} \\
(0.13)\end{array}$ & $\begin{array}{c}-0.41^{* *} \\
(0.18)\end{array}$ & $\begin{array}{l}-0.35^{*} \\
(0.16)\end{array}$ & $\begin{array}{l}-0.28^{*} \\
(0.14)\end{array}$ & $\begin{array}{r}-0.64^{*} \\
(0.33)\end{array}$ \\
\hline
\end{tabular}


Table 6: (continued)

\begin{tabular}{|c|c|c|c|c|c|c|}
\hline & Model 1 & Model 2 & Model 3 & Model 4 & Model 5 & Model 6 \\
\hline Late degree & - & $\begin{array}{c}0.02 \\
(0.05)\end{array}$ & $\begin{array}{c}0.04 \\
(0.05)\end{array}$ & $\begin{array}{c}0.04 \\
(0.05)\end{array}$ & $\begin{array}{c}0.02 \\
(0.05)\end{array}$ & $\begin{array}{c}0.03 \\
(0.06)\end{array}$ \\
\hline \multicolumn{7}{|c|}{ Employment and Economic Resources: } \\
\hline Employed & - & - & $\begin{array}{l}-0.17^{* * *} \\
(0.06)\end{array}$ & $\begin{array}{l}-0.16^{* * *} \\
(0.06)\end{array}$ & $\begin{array}{l}-0.15^{* * *} \\
(0.06)\end{array}$ & $\begin{array}{l}-0.09^{* *} \\
(0.04)\end{array}$ \\
\hline $\begin{array}{l}\text { Manager/ } \\
\text { professional }\end{array}$ & - & - & $\begin{array}{l}-0.26^{* *} \\
(0.07)\end{array}$ & $\begin{array}{l}-0.24^{* *} \\
(0.07)\end{array}$ & $\begin{array}{l}-0.19^{* *} \\
(0.07)\end{array}$ & $\begin{array}{l}-0.24^{* *} \\
(0.09)\end{array}$ \\
\hline $\begin{array}{l}\text { Household } \\
\text { income (ln) }\end{array}$ & - & - & $\begin{array}{c}0.02 \\
(0.02)\end{array}$ & $\begin{array}{c}0.02 \\
(0.02)\end{array}$ & $\begin{array}{c}0.02 \\
(0.02)\end{array}$ & $\begin{array}{c}0.03 \\
(0.02)\end{array}$ \\
\hline $\begin{array}{l}\text { Worry about } \\
\text { income }\end{array}$ & - & - & $\begin{array}{l}0.14^{* * *} \\
(0.05)\end{array}$ & $\begin{array}{l}0.12^{* *} \\
(0.05)\end{array}$ & $\begin{array}{l}0.11^{* *} \\
(0.05)\end{array}$ & $\begin{array}{c}0.02 \\
(0.07)\end{array}$ \\
\hline $\begin{array}{l}\text { Has health } \\
\text { insurance }\end{array}$ & - & - & $\begin{array}{l}-0.25^{* * *} \\
(0.06)\end{array}$ & $\begin{array}{l}-0.24^{* * *} \\
(0.06)\end{array}$ & $\begin{array}{l}-0.24^{* * *} \\
(0.06)\end{array}$ & $\begin{array}{l}-0.23^{* *} \\
(0.07)\end{array}$ \\
\hline \multicolumn{7}{|l|}{ Social Ties: } \\
\hline $\begin{array}{l}\text { Number children } \\
\text { fathered }\end{array}$ & - & - & - & $\begin{array}{c}0.01 \\
(0.03)\end{array}$ & $\begin{array}{c}0.02 \\
(0.03)\end{array}$ & $\begin{array}{c}0.03 \\
(0.03)\end{array}$ \\
\hline Ever divorced & - & - & - & $\begin{array}{c}0.04 \\
(0.05)\end{array}$ & $\begin{array}{c}0.03 \\
(0.05)\end{array}$ & $\begin{array}{c}0.06 \\
(0.06)\end{array}$ \\
\hline $\begin{array}{l}\text { Difficult } \\
\text { relationships }\end{array}$ & - & - & - & $\begin{array}{l}0.18^{* * *} \\
(0.05)\end{array}$ & $\begin{array}{l}0.19^{* * *} \\
(0.06)\end{array}$ & $\begin{array}{c}0.07 \\
(0.07)\end{array}$ \\
\hline $\begin{array}{l}\text { No socializing } \\
\text { w/friends }\end{array}$ & - & - & - & $\begin{array}{c}0.03 \\
(0.05)\end{array}$ & $\begin{array}{c}0.01 \\
(0.05)\end{array}$ & $\begin{array}{c}0.01 \\
(0.06)\end{array}$ \\
\hline \multicolumn{7}{|l|}{ Health Behaviors ${ }^{3}$ : } \\
\hline Non-drinker & - & - & - & - & $\begin{array}{c}0.07 \\
(0.05)\end{array}$ & $\begin{array}{c}0.11 \\
(0.06)\end{array}$ \\
\hline Heavy drinker & - & - & - & - & $\begin{array}{c}0.05 \\
(0.08)\end{array}$ & $\begin{array}{c}0.05 \\
(0.09)\end{array}$ \\
\hline Current smoker & - & - & - & - & $\begin{array}{l}0.25^{* * *} \\
(0.07)\end{array}$ & $\begin{array}{l}0.29^{* * *} \\
(0.09)\end{array}$ \\
\hline Ever smoked & - & - & - & - & $\begin{array}{r}0.10^{*} \\
(0.05)\end{array}$ & $\begin{array}{r}0.08^{*} \\
(0.06)\end{array}$ \\
\hline Obese & - & - & - & - & $\begin{array}{l}0.37^{* * *} \\
(0.06)\end{array}$ & $\begin{array}{l}0.34^{* * *} \\
(0.07)\end{array}$ \\
\hline \multicolumn{7}{|c|}{ Psychological Resources: } \\
\hline Personal control & - & - & - & - & - & $\begin{array}{l}0.08^{* * *} \\
(0.02)\end{array}$ \\
\hline Competency & - & - & - & - & - & $\begin{array}{l}-0.23^{* * *} \\
(0.04)\end{array}$ \\
\hline
\end{tabular}


Table 6: (continued)

\begin{tabular}{lcccccc}
\hline & Model 1 & Model 2 & Model 3 & Model 4 & Model 5 & \multicolumn{1}{c}{ Model 6 } \\
\hline Direct Effects: & & & & & & \\
Poor health & $0.38^{* * *}$ & $0.34^{* * *}$ & $0.33^{* * *}$ & $0.33^{* * *}$ & $0.31^{* * *}$ & \multicolumn{1}{c}{$0.34^{* * *}$} \\
W1 \& W2 & $(0.06)$ & $(0.05)$ & $(0.05)$ & $(0.05)$ & $(0.05)$ & $(0.05)$ \\
Log likelihood & -886.63 & -1861.60 & -1825.63 & -1820.25 & -1790.44 & -1745.16 \\
BIC & 3903.54 & 3918.61 & 3882.87 & 3901.06 & 3877.62 & 3801.39 \\
Covariate R $\mathrm{R}^{2}$ & 0.07 & 0.08 & 0.09 & 0.09 & 0.11 & 0.13 \\
\hline
\end{tabular}

${ }^{*} \mathrm{p}<.05,{ }^{* *} \mathrm{p}<.01,{ }^{* * *} \mathrm{p}<.001$

${ }^{1}$ Omitted reference category is non-school attendee cluster.

${ }^{2}$ Omitted reference categories are no high school degree versus the included degrees and ontime degree versus late degree.

${ }^{3}$ Omitted reference categories are moderate drinkers, never smoked, and not obese.

or slower junior college-grad trajectory has persistent effects at the same levels as for women. Timing of degree completion has no effect. Heath behaviors such smoking and obesity have expected health effects. Psychosocial factors behave similarly for men as for women.

Finally, LC models make the assumption of local independence. This means that observed responses to the manifest variables are assumed to be independent given that latent class membership is taken into account. In other words, when all latent classes are controlled, only a random relationship remains between the response (dependent) variables and the covariates (explanatory variables) that are associated with latent class membership. Violating the assumption of local independence means two indicators are more strongly related than can be explained by clusters. We test the assumption of local independence and specify direct effects between covariates and indicators if they are correlated within classes. These are reported in the last row of Tables 5 and 6, where the net direct effects of health at wave 1 on health at wave 2 are controlled. This control has a significant net effect on health trajectory placement, but it also supports the robustness of the other covariate estimates discussed above.

\section{Discussion}

Cumulative advantage theory fits well with temporally-driven analyses of inequality processes. It predicts the persistence and growth of inequality as cohorts age. Initial inequalities condition subsequent probabilities of gaining or losing resources. In this vein, childhood adversity is a fundamental source of life course inequality that operates directly and indirectly through educational, work, and family careers to affect personal resources over time, including health. Childhood conditions select individuals into different educational trajectories that provide differential exposures to learning. Women are more vulnerable to the anchoring effects of childhood conditions in their later health. These exposures vary in their frequency and duration over the life course and in their content and diversity over the educational career. 
Men's and women's trajectories of poor health are similar but do not converge with age. And, the factors that influence men's health are different. Childhood effects disappear with later role transitions, but only the highest educational achievement levels - post-baccalaureate degrees - appear to provide protective effects for men. Hence, the returns from college participation and completion are not as high as they are for women. These differences conform to recent reports of women's higher life course returns from baccalaureate completion, which include greater marriageability, higher standards of living and protection from poverty (DiPrete and Buchmann 2006).

Educational attainment and health are positively associated and interdependent in aging populations. Significant minorities of individuals continue educational participation well into middle age as health patterns begin to diverge in aging populations. How are these related in time? First, it appears from these analyses that the timing of educational credential attainment is a strong driver of this relationship especially among women. On-time achievement of academic degrees has strong positive effects on health, net of degree completion. Low achievement and off-time achievement are themselves stratified indicators of disadvantage. Delays in educational attainment are associated with high school and post-secondary drop-out rates, entry into vocational/technical or two-year programs instead of four-year programs, and non-completion of degrees - all of which have been found to be associated with economic, health, or social disadvantages (Bozick and DeLuca 2005; Bumpass and Call 1989; McClelland 1990). So, 13 to 15 years of completed schooling may add up to more than 12 (or less than 12) years of schooling, but the institutional contexts of these achievement levels involve unmeasured life course factors that are ultimately relevant to health.

Late educational timing may also influence health in another way. Because education during middle age remains "non-normative" or off-time, it is a potential source of stressors with negative health implications. Educational participation at this age is influenced by other adult roles and role transitions. For example, fertility and union formation in midlife affect school enrollment decisions (Upchurch, McCarthy, and Ferguson 1993; Thornton, Axinn, and Teachman 1995).

Similarly, work obligations coupled with family responsibilities amplify stressors that create role conflicts and affect health, especially for women (Hamil-Luker and O'Rand 2007). Accordingly, more years of schooling in off-time trajectories may introduce costs as well as benefits from more education. Second, besides timing effects, enrollment track effects need further exploration. Postsecondary credentials impart more than knowledge, skills, and social experience. They act as "signals" in market environments that are reinforced in their own right, without reference to specific individual levels of knowledge. As such, they are structural mechanisms that sort workers in the labor market and marital partners in the marriage market (Sweeney 2002). Employers pay wage and benefit premiums to credentials, above and beyond skill requirements (Spence 1973). They also have positional implications. Credentials also lead to "better jobs," i.e. positions in organizations that offer more autonomy and control over the work process. These positional differences are also likely to have health implications. Without separating kinds of credentials attained over the life course, the chance increases of missing other sources of stress that affect health. 
Also, upwardly mobility rather than non-mobility within and across tracks probably has health and other outcomes. Baccalaureate-granting tracks are sources of social mobility and clearly more highly rewarded than non-baccalaureate tracks. But our study reveals that very little movement occurs between tracks (also reported by Elman and O'Rand 2007). This pattern reflects strong path dependence in educational trajectories. In our study, the academic track consisting of Junior College enrollment followed by four-year college and graduate enrollment is perhaps a socially mobile track, but its more delayed completion patterns increase the risks for poor health when compared to the faster university track.

Vocational schooling may not provide comparable human capital benefits as fouryear programs. Skills acquisition, socialization, and social relationships (or perhaps the relative absence of these) are different in these institutional environments. Technically centered curricula do not promote the broader synthetic and analytic cognitive styles that enhance the kinds of rational and self-confident resources that have been associated with any form of education in earlier research (Ross and Mirowsky 1999). Similarly, the commuter experiences that typify the two-year school experience limit the potential for immersion in the learning experience whatever the content. Consequently, a lower sense of self-efficacy and a tendency to delay or drop-out are increased (Alba and Lavin 1981; Ainsworth and Roscigno 2005).

Finally, the obvious costs of non-high school completion or high school completion only replicate the findings of earlier studies. A significant share of the education-health correlation is produced at the lower margin of the distribution. Non-attendees have the highest probability of being placed in the poor health trajectory. A considerable literature documents that these educationally disadvantaged groups are increasingly marginalized from labor and marriage markets in the current context (Bernhardt et al. 2001). One might argue that their experience is perhaps better considered as qualitatively different and not just different by degree - and particularly with regard to health outcomes. However, we have raised the additional question of whether the experiences of those on other trajectories may also have meaningful qualitative differences given the diverse exposures of different trajectories to different social stressors over the life course. Childhood disadvantage and non-post secondary educational attainment initiate what is perhaps a more highly path dependent process than other origin statuses.

The linkages among childhood conditions, educational trajectories, and health outcomes are only beginning to be understood. The complex mix of family backgrounds, educational careers, and health outcomes has yet to be completely identified and the specific pathways between the aspects of individuals' backgrounds and their opportunities for resource accumulation determined. In the case of the education variable, which appears to be central among these linkages, much is left to explore.

\section{Appendix}

The methods used here apply finite mixture models in the form of simple latent class cluster models to identify population heterogeneity in school enrollment and poor health trajectories. Because the indicators are dichotomous measures of whether or not respond- 
ents reported fair or poor health at wave $t$ and enrolled in different types of schools at various age groupings, we specify a finite mixture of logistic regression models (see, e.g., Ham and Rea 1987). Adapting the finite mixture log-likelihood function given in Land et al. (1996) for Poisson mixtures, the log-likelihood for the finite mixture logistic regression model can be written as:

$$
\log \mathrm{L}=\sum_{i=1}^{N} \log \left[\sum_{j=1}^{J} m^{j} \cdot \operatorname{Pr}^{j}\left(Y_{i} \mid x_{i}, \theta^{\mathrm{j}}\right)\right], \mathrm{m}^{\mathrm{j}} \geq 0, \sum_{\mathrm{j}=1}^{\mathrm{J}} \mathrm{m}^{\mathrm{j}}=1,
$$

where

- $m^{j}$ denotes the proportion of the population who are members of the $j$ th latent class (cluster, grouping), and

- $\quad \operatorname{Pr}^{j}\left(Y_{i} \mid x_{i}, \theta^{i}\right)$ denotes the logistic regression function for individual $i$ in latent class $j$ having value $Y_{i}$ on the response (dependent) variable, measured covariates $x_{i}$, and logistic regression parameters in the vector $\theta^{j}$.

To obtain estimates of the $m^{j}$ and $\theta^{j}$ parameters, this log-likelihood is maximized using all sample members and observed patterns of school enrollment and poor health.

\section{References}

Ainsworth, J. W., \& Roscigno, V. J. (2005). Stratification, school-work linkages and vocational education. Social Forces, 84, 257-284.

Alba, R., \& Lavin, D. (1981). Community colleges and tracking in higher education. Sociology of Education, 54, 223-237.

Bandeen-Roche, K., Miglioretti, D. L., Zeger, S. L., \& Rathouz, P. J. (1997). Latent variable regression for multiple discrete outcomes. Journal of the American Statistical Association, 92, 1375-1386.

Bernhardt, A., Morris, M., Hancock, M. S., \& Scott, M. A. (2001). Divergent paths: Economic mobility in the new American labor market. New York: Russell Sage Foundation.

Blackwell, D., Hayward, M., \& Crimmins, E. (2001). Does childhood health affect chronic morbidity in later life? Social Science and Medicine, 52, 1269-1284.

Blau, F. D. (1998). Trends in the well-being of American women, 1970-1995. Journal of Economic Literature, 36, 112-165.

Bozick, R., \& DeLuca, S. (2005). Better late than never? Delayed enrollment in the high school to college transition. Social Forces, 84, 531-554.

Bumpass, L., \& Call, V. R. A. (1989). The timing of marriage and education (NSFH Working Paper \#10). Madison, WI: University of Wisconsin.

Case, A., Lubotsky, D., \& Paxson, C. (2002). Economic status and health in childhood: The origins of the gradient. American Economic Review, 92 (5),1308-34.

Dannefer, D. (2003). Cumulative advantage/disadvantage and the life course: Cross-fertilizing age and social science. Journal of Gerontology-SS, 58, 327-337.

DiPrete, T. A., \& Buchmann, C. (2006). Gender-specific trends in the value of education and the emerging gender gap in college completion. Demography, 43, 1-24.

DiPrete, T. A., \& Eirich, G. M. (2006). Cumulative advantage as a mechanism for inequality: A review of theoretical and empirical developments. Annual Review of Sociology, 32, 271-297. 
Elman, C., \& O'Rand, A. M. (2002). Perceived labor market insecurity and entry into work-related education and training among adult workers. Social Science Research, 31, 49-76.

Elman, C., \& O'Rand, A. M. (2004). The race is to the swift: Socioeconomic origins, adult education, and wage attainment. American Journal of Sociology, 110, 123-160.

Elman, C., \& O'Rand, A. M. (2007). The effects of social origins, life events, and institutional sorting on adults' school transitions, 1987-1994. Social Science Research, 36 (3), 1276-1299.

Elo, I. (1998). Childhood conditions and adult health: Evidence from the Health and Retirement Study (Population Aging Research Center Working Paper 98-03). Philadelphia: University of Pennsylvania.

Epstein, C. F., \& Kalleberg, A. L. (Eds.) (2004). Fighting for time: Shifting boundaries of work and social life. New York: Russell Sage Foundation.

Goldin, C., Katz, L. F., \& Kuziemko, I. (2006). The homecoming of American college women: The reversal of the college gender gap. Journal of Economic Perspectives, 20, 133-156.

Gornick, J. C., \& Meyers, M. K. (2003). Families that work. New York: Russell Sage Foundation.

Ham, J. C., \& Rea, S. A. (1987). Unemployment insurance and male unemployment duration in Canada. Journal of Labor Economics, 5, 325-353.

Hamil-Luker, J., \& O'Rand, A. M. (2007). Gender differences in the link between childhood socioeconomic conditions and heart attack risk in adulthood. Demography, 44 (1), 137-158.

Harper, S., Lynch, J., Hsu, W.-L., Eversona, S. A., Hillemeiera, M. H., Raghunathanb, T. E., et al.(2002). Life course socioeconomic conditions and adult psychosocial functioning. International Journal of Epidemiol, 31, 395-403.

Hayward, M. D., \& Gorman, B. K. (2004). The long arm of childhood: The influence of early life social conditions on men's mortality. Demography, 41 (1), 87-107.

House, J. S., Lantz, P. M., \& Herd, P. (2005). Continuity and change in the social stratification of aging and health over the life course: Evidence from a nationally representative longitudinal study from 2986 to 2001/2. Americans' Changing Lives Study. Journal of Gerontology-SS, $60 B$ (Special Issue II), 15-26.

Jacobs, J. A., \& Stoner-Eby, S. (1998). Adult enrollment and educational attainment. Annals of the American Academy of Political and Social Science, 559 (September), 91-108.

Kuh, D., \& Davey-Smith, G. (1997). A life course approach to chronic disease epidemiology. New York: Oxford University Press.

Land, K., McCall, P. L., \& Nagin, D. S. (1996). A comparison of poisson, negative binomial, and semiparametric mixed poisson regression models, with empirical applications to criminal careers data. Sociological Methods and Research, 24, 387-442.

McClelland, K. (1990). Cumulative disadvantage among the highly ambitious. Sociology of Education, 63, 102-121.

McLeod, J. D., \& Almazan, E. P. (2003). Connections between childhood and adulthood. In J. T. Mortimer \& M. J. Shanahan (Eds.), Handbook of the life course (pp. 391-411). New York: Kluwer Academic/Plenum Publishers.

Mirowsky, J., \& Ross, C. E. (2003). Education, social status, and health. New York: de Gruyter.

Monks, J. (1997). The impact of college timing on earnings. Economics of Education Review, 16, $419-423$.

Nagin, D. (2005). Group based modeling of development. Cambridge, MA: Harvard University Press.

O'Rand, A. M. (2001). Stratification and the life course: The forms of life course capital and their interrelationships. In R. B. Binstock \& L. K. George (Eds.), Handbook on aging and the social sciences (pp. 197-216). New York: Academic Press.

O'Rand, A. M., \& Hamil-Luker, J. (2005). Processes of cumulative adversity linking childhood disadvantage to increased risk of heart attack. Journal of Gerontology-SS, 60B (Special Issue II), $117-124$. 
Reynolds, J., \& Ross, C. (1998). Social stratification and health: Education's benefit beyond economic status and social origins. Social Problems, 45, 221-247.

Rieker, P. P., \& Bird, C. E. (2000). Sociological explanations of gender differences in mental and physical health. In C. Bird, P. Conrad \& A. M. Fremont (Eds.), Handbook of medical sociology (pp. 98-113). Upper Saddle River, NJ: Prentice-Hall.

Ross, C. E., \& Mirowsky, J. (1989). Explaining the social patterns of depression: Control and problem-solving - or support and talking. Journal of Health and Social Behavior, 30, 206-219.

Ross, C. E., \& Mirowsky, J. (1999). Refining the association between education and health: The effects of quantity, credential and selectivity. Demography, 36 (4), 445-460.

Schnittker, J. (2007). Working more and feeling better: Women's health, employment, and family life, 1974-2004. American Sociological Review, 72 (2), 221-238.

Spence, M. (1973). Job market signaling. The Quarterly Journal of Economics, 87, 355-74.

Stevens, G., \& Cho, J. H. (1985). Socioeconomic indexes and the new 1980 census occupational classification scheme. Social Science Research, 14, 142-168.

Sweeney, M. (2002). Two decades of family change: The shifting economic foundations of marriage. American Sociological Review, 67, 12-147.

Sweet, J. A., Bumpass, L. L., \& Call, V. (1988). The design and content of the National Survey of Families and Households (NSFH Working Paper 1). Madison, WI: Center for Demography and Ecology, University of Wisconsin-Madison.

Taniguchi, H. (2005). The influence of age at degree completion on college wage premiums. Research in Higher Education, 46, 861-881.

Taniguchi, H., \& Kaufman, G. (2005). Degree completion among nontraditional college students. Social Science Quarterly, 86, 912-927.

Thornton, A., Axinn, W. G., \& Teachman, J. D. (1995). The influence of school enrollment and accumulation on cohabitation and marriage in early adulthood. American Sociological Review, 60, 762-774.

Upchurch, D., McCarthy, J., \& Ferguson, L. R. (1993). Childbearing and schooling: Disentangling temporal and causal mechanisms. American Sociological Review, 58, 735-740.

U.S. Department of Education Science \& National Center for Education Statistics (2006). The condition of education 2006. Retrieved 12.06.2009: https://nces.ed.gov/pubsearch/pubsinfo. asp?pubid $=2006071$

U.S. Department of Education Science \& National Center for Education Statistics (2001). Baccalaureate and beyond longitudinal study: 2000/01 Follow-up field test methodology report (B\&B:2000/01). Retrieved 12.06.2009: http://nces.ed.gov/pubs2001/200115.pdf

U.S. Department of Education Science \& National Center for Education Statistics (2000). Dropout rates in the United States: 2000. Retrieved 12.06.2009: http://nces.ed.gov/pubs2002/2002114. pdf

Vermunt, J. K., \& Magidson, J. (2000). Latent class cluster analysis. In J. A. Hagenaars \& A. L. McCutcheon. (Eds.), Advances in latent class models. Cambridge, UK: Cambridge University Press.

Wickrama, K. A. S., Lorenz, F. O., \& Conger, R. D. (1997). Parental support and adolescent physical health status: A latent growth-curve analysis. Journal of Health and Social Behavior, 38, 149-163.

Yamaguchi, K. (2000). Multinomial logit latent-class regression models: An analysis of the predictors of gender-role attitudes among Japanese women. American Journal of Sociology, 105, $1702-1740$. 